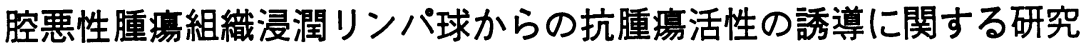

\section{森良之 \\ Studies on induction of antitumor cytotoxicity on tumor infiltrating lymphocytes of patients with oral malignant tumors}

\author{
Yoshiyuki MORI
}

\begin{abstract}
Previous reports indicated that the histological intensity of the tumor infiltrating lymphocytes (TIL), which is one of the manifestations of immunological host's response against malignant tumor cells, correlates with the clinical prognosis of the cancer patients.

In the present study, we investigated the antitumor cytotoxicity of TIL (or LN-TIL: lymphocytes of metastatic lymph node) induced by anti-CD3 antibody and interleukin 2 (IL2 ), and the availability for the source of the adoptive immunotherapy on patients with oral malignant tumors.

TIL were isolated from 28 tumors and LN-TIL were isolated from 6 metastatic lymph nodes obtained from 28 patients with oral malignant tumors.

Natural killer (NK) and lymphokine-activated killer (LAK) activity of freshly isolated TIL were usually undetectable. However the antitumor cytotoxicity of TIL was generated with IL-2 in vitro culture. These activated TIL showed high levels of NK and LAK activities, and these were prolonged more than those of PBL.

On the other hand, freshly isolated TIL from patients who received IL-2 injection directly into the tumor lesions before surgery, showed NK and LAK activities.

The growth of TIL were obviously enhanced by using the plates coated with anti-CD3 antibody at the beginning of the culture.

These activated TIL (or LN-TIL) with anti-CD3 antibody and/or IL-2 also showed the cytotoxicity against the autologous tumor cells.

These results indicate that anti-CD3 antibody and IL-2 augment the specific and/or nonspecific cytotoxicity of the TIL (or LN-TIL) against the tumor cells, and this augmentation of cytotoxic activity shows the anti-tumoral efficacy for oral malignant tumors. Furthermore, TIL (or LN-TIL) from oral malignant tumors could be on appropriate effector cells for adoptive immunotherapy on the patients with oral malignant tumors.
\end{abstract}

Key words: oral malignant tumor (口腔覀性腫瘍), tumor infiltrating lymphocytes (TIL) (腫 瘍組織浸潤 リンパ球), interleukin 2 (IL-2) (インターロイキン 2), anti-CD3 antibody (抗 CD3 抗体), antitumor cytotoxicity (抗腫湯活性)

東京医科歯科大学歯学部口腔外科学第 2 講座 （主任：榎本昭二教授）

The 2nd Department of Oral and Maxillofacial
Surgery, Faculty of Dentistry, Tokyo Medical and Dental University (Chief: Prof. Shoji Enomoto) 


\section{緒}

\section{言}

ヒト悪性腫瘍組織には単核細胞浸潤があり，その浸潤 の程度と患者の予後とが密接に関連していることが覀性 黑色腫例 ${ }^{1)}$ で報告されている。 また，胃癌2) の症例では 原発癌組織間質にリンパ球浸潤が強いほど予後良好で, 5 年生存率と相関することが報告されている。これらの 理由から悪性腫瘍に浸潤するリンパ球は，古くから腫瘍 免疫反応の表現の 1 つして興味がもたれてきた。

口腔癌に扣いても原発癌組織間質にリンパ球浸潤が強 いほど，予後良好で 5 年生存率と相関する傾向が認めら

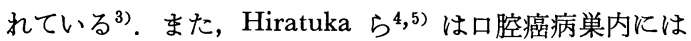
$\mathrm{T}$ 細胞浸潤が多いことを報告している，すなわち，原発 腫瘍が小さい症例，また頸部リンパ節転移のない症例で T細胞浸潤が強く認められること, またブレオマイシン による腫瘍縮小率と生検時の $\mathrm{T}$ 細胞浸潤の強さとが相関 するという口腔癌組織に括ける $\mathrm{T}$ 細胞浸潤の臨床的重要 性を述べている.

このように腫瘍組織に対する宿主の免疫学的防御反応 があるとすれば，それは腫瘍の増殖局所において最も端 的にあらわれると考えられる.

そこで，口腔悪性腫瘍組織に扣いても，リンパ系細胞 が腫瘍の増殖を抑える上で重要な役割を果たしていると いら観点に立てば，局所に 浸潤する 単核細胞浸潤（腫 瘍組織浸潤リンパ球 : Tumor infiltrating lymphocytes (TIL)）の機能を解析することはきわめて重要であると 考えられる。ささらに腫瘍細胞が転移している所属リンパ 節組織のリンパ 球（転移リンパ節リンパ球 : 以下 LNTIL) に打いても同様の重要性が考えられる.

一方，1976 年に Morgan6) らにより T cell growth factor (TCGF) が発見され，のちに Interleukin-2(IL2）と命名されて以来，遺伝子工学技術の進歩により遺 伝子組換光 IL-2 (recombinant IL-2, rIL-2) が大量 に供給可能となった ${ }^{7)}$.

この IL-2 で癌患者の末梢血リンパ球 (peripheral blood lymphocytes: PBL) を刺激すると, 自己固形腫瘍 を含む各種の 癌細胞に 対して強い細胞障害活性を示す lymphokine-activated killer (LAK) 細胞が誘導される ことが Rosenberg らのグループにより報告され ${ }^{8)}$, 今ま でに IL-2 の単独投与あるいは in vitro で大量に誘導し た LAK 細胞を用いた養子免疫療法 ${ }^{9 \sim 11}$ が盛んに行われ ている。

また Rosenberg らは担癌マウスに対する TIL 移入は LAK 養子免疫療法の50１00倍 in vivo 治療効果がある ことを報告し ${ }^{12)}$ ，それにつついて転移性メラノーマに対 する臨床治験を行い TIL 移入による高い治療効果を報 告している ${ }^{13)}$. このように養子免疫療法の効果を一層増 強させるための移入細胞として，腫瘍組織に対する宿主
の免疫学的防御反応と考えられる TIL を用いる研究も 盛んに行われるようになってきている.

また，この養子免疫療法に用いる移入細胞の細胞障害

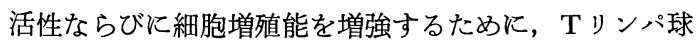

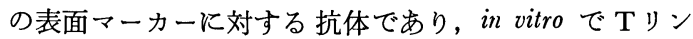
パ球にマイトジェニックに作用する抗 CD3 抗体を用い て, Tリンパ球を効率よく増殖させる方法も試みられて いる ${ }^{14 \sim 19)}$.

そこで今回，口腔覀性腫瘍における TIL および LNTIL の機能を解析する 1 つ側面として, 抗腫瘍活性の 誘導について検索を行い,さらに口腔悪性腫瘍に対する 養子免疫療法に用いる移入細胞の有用性をあきらかにす ることを目的として以下の検討を行った.

すなわち，口腔悪性腫瘍患者から TIL を分離し， IL-2 による in vitro での細胞障害活性および細胞増殖 能の増強を試み, 抗腫瘍活性誘導の可能性について検討 した。 また，術前治療として腫瘍組織周囲に IL-2 の局 所投与を行い, 切除標本より分離された新鮮 TIL の細 胞障害活性（NK および LAK 活性）を測定し，IL-2 の腫瘍局所投与による TIL の抗腫瘍免疫能誘導の可能 性について検討した。ささらに， T細胞を選択的に増殖さ せることを目的として，抗 CD3 抗体执よび IL-2 を用 いて TIL および LN-TIL について同様の検索を行い， 養子免疫療法の移入細胞としての有用性について検討し た。

\section{研 究 方 法}

\section{1. 研究対象}

研究対象は, 1987 年 5 月より1990年 8 月までの 3 年 4 か月間に東京医科歯科大学歯学部第 2 口腔外科で腫瘍切 除手術が行われた, 口腔悪性腫瘍患者のうちから任意に 選択した 28 名である，検索組織は，腫瘍原発組織 28 検 体, 腫瘍転移のある所属頸部リンパ節 6 検体であった. 検索した腫瘍原発組織の内訳は, 部位別では上顈10例, 舌 8 例, 下顎 5 例, 頓粘膜 2 例, 口底, 顎下腺, 口峡咽 頭部がそれぞれ 1 例ずつであり, 組織型別では, 扁平上 皮癌22例, 悪性黒色腫 2 例, 横紋笳肉腫, 骨肉腫, 粘表 皮癌，腺様豊胞癌がそれぞれ 1 例ずつであった。腫瘍転 移リンパ節の組織型は, 扁平上皮癌 5 例, 悪性黒色腫 1 例であった. 切除された腫瘍原発組織の病理組織標本に よる腫瘍局所のリンパ球浸潤度は Black $5^{20)}$ の LIgrade に従った。 また癌の臨床的進行度は1987年 UICC 提案 の Stage 分類に従った（表 1,2）. 比較対象の末梢血 リンパ球は検体の得られた同一個人より採取した。

\section{IL-2 の局所投与}

症例13〜20までの 8 例に対して, 原則として $0.7 \times 10^{6}$ JRU のレコンビナント IL-2（rIL-2:S6820, 塩野義 製薬) を $1 \%$ キシロカイン囚に溶解後, 腫瘍周囲組織に 
表 1 口腔悪性腫瘍組織より分離され IL-2単独で培養された腫瘍組織浸潤リンパ球 (TIL)

\begin{tabular}{|c|c|c|c|c|c|c|c|c|}
\hline \multicolumn{2}{|c|}{ 症 例 } & 診断 (TNM stage) & 術前治療 & $\begin{array}{l}\text { LI } \\
\text { grade }\end{array}$ & 回収細胞数 & $\mathrm{L} / \mathrm{T}$ 比 & $\begin{array}{c}\text { 最大獲得細胞数 } \\
\text { (日) }\end{array}$ & 培養可能日数 \\
\hline 1. & $56 \mathrm{M}$ & $\begin{array}{l}\text { 顎下腺 } \\
\text { Mucoepid. Ca. } \\
\text { (T3aN2bM1 IV) }\end{array}$ & $\begin{array}{l}\text { MTX: } 225 \mathrm{mg} \\
\text { 5FU : } 1,500 \mathrm{mg} \\
\text { i.v.* }\end{array}$ & $\mathrm{ND}^{1)}$ & $0.86 \times 10^{6}$ & $\mathrm{ND}^{2)}$ & $5.15 \times 10^{7}(21)$ & 21(凍結保存) \\
\hline 2. & $57 \mathrm{M}$ & $\begin{array}{l}\text { 下顎宷肉 } \mathrm{SCC} \\
\text { (T4N0M0 IV) }\end{array}$ & 施行せず & 3 & $0.21 \times 10^{6}$ & ND & $1.15 \times 10^{8}(56)$ & 83(細菌污染) \\
\hline 3. & $62 \mathrm{~F}$ & $\begin{array}{l}\text { 下顎歯肉 } \\
\text { (T3N1M0 }\end{array}$ & $\begin{array}{l}\text { MTX: } 150 \mathrm{mg} \\
\text { 5FU: } 2,000 \mathrm{mg} \\
\text { i.v. }\end{array}$ & 3 & $3.30 \times 10^{6}$ & ND & $6.60 \times 10^{7}(21)$ & 34（細菌污染） \\
\hline 4. & $44 \mathrm{~F}$ & $\begin{array}{l}\text { 上顎洞 } \mathrm{SCC} \\
\text { (T4N0M0 IV) }\end{array}$ & $\begin{array}{l}\text { Linac } 4 \mathrm{MV} \\
\text { Xray } 25 \mathrm{~Gy}\end{array}$ & 2 & $3.40 \times 10^{6}$ & ND & 4. $42 \times 10^{7}(28)$ & 35(測定） \\
\hline 5. & $69 \mathrm{~F}$ & $\begin{array}{l}\text { 上顎洞 } \\
\text { Osteosarcoma }\end{array}$ & 施行せず & 2 & $8.50 \times 10^{6}$ & 1.9 & $3.31 \times 10^{7}(27)$ & 33(測定） \\
\hline 6. & $51 \mathrm{M}$ & 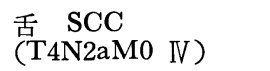 & $\begin{array}{l}\text { Linac } 4 \mathrm{MV} \\
\text { Xray } 30 \mathrm{~Gy}\end{array}$ & 1 & $\begin{array}{l}0.31 \times 10^{6} \\
(1.6 \mathrm{~g})\end{array}$ & 3.2 & 増殖せず & - \\
\hline 7. & $65 \mathrm{~F}$ & $\begin{array}{l}\text { 上顎歯肉 } \\
\text { (T2NOM0 }\end{array}$ & 施行せず & 1 & $\begin{array}{l}0.13 \times 10^{6} \\
(0.2 \mathrm{~g})\end{array}$ & ND & 増殖せず & \\
\hline 8. & $31 \mathrm{M}$ & $\begin{array}{l}\text { 舌 } \\
(\mathrm{rTCC} \\
(\mathrm{TxN} 2 \mathrm{aM} 0 \mathrm{IV})\end{array}$ & 施行せず & 2 & $\begin{array}{l}1.03 \times 10^{6} \\
(0.7 \mathrm{~g})\end{array}$ & 2.7 & $2.32 \times 10^{7}(23)$ & 23(凍結保存) \\
\hline 9. & $60 \mathrm{M}$ & $\begin{array}{l}\text { 舌 } \mathrm{SCC} \\
(\mathrm{T} 2 \mathrm{~N} 1 \mathrm{M} 0 \text { III) }\end{array}$ & 施行せず & ND & $\begin{array}{c}5.70 \times 10^{6} \\
(0.85 \mathrm{~g})\end{array}$ & 5.3 & 8. $43 \times 10^{7}(16)$ & 35(測定) \\
\hline 10. & $74 \mathrm{M}$ & $\begin{array}{ll}\text { 下顎歯肉 } & \text { SCC } \\
\text { (T3N0M0 } & \text { III) }\end{array}$ & $\begin{array}{l}\text { MTX: } 750 \mathrm{mg} \\
\text { 5FU: } 500 \mathrm{mg} \\
\text { i.v. }\end{array}$ & ND & $\begin{array}{l}0.56 \times 10^{6} \\
(0.5 \mathrm{~g})\end{array}$ & 1.0 & $2.18 \times 10^{6}(9)$ & 14（細菌污染） \\
\hline 11. & $68 \mathrm{M}$ & $\begin{array}{ll}\text { 下顎歯肉 } & \text { SCC } \\
(\text { T2N0M0 II) }\end{array}$ & 施行せず & 2 & $\begin{array}{l}1.60 \times 10^{6} \\
(0.25 \mathrm{~g})\end{array}$ & 1.9 & すべて測定に伍 & 吏用（培養せず） \\
\hline 12. & $18 \mathrm{M}$ & $\begin{array}{l}\text { 上顎洞 } \\
\text { Rhabdomyosarcoma }\end{array}$ & 施行せず & 1 & $\begin{array}{l}4.00 \times 10^{6} \\
(0.8 \mathrm{~g})\end{array}$ & 1.0 & $3.56 \times 10^{9}(37)$ & 51（測定） \\
\hline 13. & $72 \mathrm{~F}$ & $\begin{array}{l}\text { 舌 } \\
\text { (TCC } \\
\text { T3M0 III) }\end{array}$ & $\begin{array}{l}\text { IL-2 局注 } \\
8.4 \times 10^{6} \mathrm{JRU}\end{array}$ & 3 & $8.33 \times 10^{6}$ & ND & すべて測定に侈 & 吏用 7 (測定) \\
\hline 14. & $64 \mathrm{M}$ & $\begin{array}{l}\text { 煩粘膜 } \quad \text { SCC } \\
(\mathrm{T} 4 \mathrm{~N} 1 \mathrm{M} 0 \mathrm{IV})\end{array}$ & $\begin{array}{l}\text { IL-2 局注 } \\
15.4 \times 10^{6} \mathrm{JRU}\end{array}$ & 3 & $9.60 \times 10^{6}$ & ND & すべて測定に仡 & 吏用（培養せず） \\
\hline 15. & $45 \mathrm{M}$ & $\begin{array}{l}\text { 舌 } \quad \text { SCC } \\
(\mathrm{rT} 2 \mathrm{~N} 0 \mathrm{M} 0 \text { II })\end{array}$ & $\begin{array}{l}\mathrm{IL}-2 \text { 局注 } \\
14 \times 10^{6} \mathrm{JRU}\end{array}$ & 3 & $1.80 \times 10^{6}$ & ND & 1. $08 \times 10^{8}(25)$ & 25(測定） \\
\hline 16. & $59 \mathrm{M}$ & $\begin{array}{l}\text { 舌 } \mathrm{SCC} \\
(\mathrm{T} 1 \mathrm{~N} 1 \mathrm{M} 0 \text { III) }\end{array}$ & $\begin{array}{l}\mathrm{IL}-2 \text { 局注 } \\
12.6 \times 10^{6} \mathrm{JRU}\end{array}$ & 3 & $4.90 \times 10^{6}$ & ND & $1.91 \times 10^{7}(13)$ & 13(測定) \\
\hline 17. & $63 \mathrm{~F}$ & $\begin{array}{ll}\text { 口陕咽頭 } & \text { SCC } \\
(\mathrm{T} 2 \mathrm{~N} 1 \mathrm{M} 0 & \text { III) }\end{array}$ & $\begin{array}{l}\text { IL-2 局注 } \\
14.7 \times 10^{6} \mathrm{JRU}\end{array}$ & $\mathrm{ND}$ & $1.60 \times 10^{6}$ & ND & 2. $49 \times 10^{7}(13)$ & 39 (細菌死滅) \\
\hline 18. & $58 \mathrm{M}$ & $\begin{array}{l}\text { 口蓋 } \mathrm{SCC} \\
(\mathrm{T} 2 \mathrm{~N} 0 \mathrm{M} 0 \text { II })\end{array}$ & $\begin{array}{l}\mathrm{IL}-2 \text { 局注 } \\
8.4 \times 10^{6} \mathrm{JRU}\end{array}$ & 3 & $0.13 \times 10^{6}$ & 6.0 & 増殖せず & \\
\hline 19. & $64 \mathrm{M}$ & $\begin{array}{l}\text { SCC } \\
\text { (rT2N0M0 II) }\end{array}$ & $\begin{array}{l}\text { IL-2 局注 } \\
13.3 \times 10^{6} \mathrm{JRU}\end{array}$ & 3 & $0.60 \times 10^{6}$ & 3.4 & すべて測定に使 & 吏用（培盖せず） \\
\hline 20. & $70 \mathrm{~F}$ & $\begin{array}{l}\text { 煩粘膜 } \\
\text { (rT2N0M0 II) }\end{array}$ & $\begin{array}{l}\text { IL-2 局注 } \\
29.4 \times 10^{6} \mathrm{JRU}\end{array}$ & 3 & $\left|\begin{array}{l}0.63 \times 10^{6} \\
(0.6 \mathrm{~g})\end{array}\right|$ & 3.2 & $2.33 \times 10^{6}(11)$ & 28(測定） \\
\hline
\end{tabular}

培着可能日数でのカッコ内は, 培湌中止理由を示す.

* : 経静脈的投与, $\mathrm{ND}^{1)}$ : LI-grade の確認されていない検体, $\mathrm{ND}^{2)}$ : 腫瘍細胞が不明瞭で $\mathrm{L} / \mathrm{T}$ 比が算出不能 な検体。

連日注射した．投与期間は12〜22日であった（表 1 ）.

\section{3. リンパ球の分離 ${ }^{21)}$}

1) 末梢血リンパ球 (PBL) の分離

腫瘍切除術施行日の早朝にヘパリン加採血した被検者 の末梢静脈血を, リン酸緩衝液 (PLS: 日水製薬) で2
〜3 倍に希釈し, リンパ球分離溶液（リンホセパール： IBL 社製, 比重1.077) を用いて比重遠心法 (900G, 10 分間）で分離した。生じた分離界面上の細胞層を採取 し，非働化牛胎児血清 (HI, FCS) $2.5 \%$ を含むPBS で 3 回洗浄後，下記の Complete Medium (CM) 中に 
表 2 口腔悪性腫瘍組織より分離され抗 CD3 抗体おょび IL-2 で培養された腫瘍組織浸潤りンパ球 (TILおよ び LN-TIL)

\begin{tabular}{|c|c|c|c|c|c|c|c|c|}
\hline 症 & 例 & 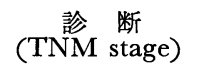 & 術前治療 & $\begin{array}{l}\text { LI } \\
\text { grade }\end{array}$ & 回収細胞数 & $\mathrm{L} / \mathrm{T}$ 比 & $\begin{array}{c}\text { 最大隻得細胞数 } \\
\text { (日) }\end{array}$ & 培養可能日数 \\
\hline 21. & $63 \mathrm{M}$ & $\begin{array}{ll}\text { 下顎㐘肉 } & \text { SCC } \\
(\mathrm{T} 4 \mathrm{~N} 0 \mathrm{M} 0 & \mathrm{N})\end{array}$ & $\begin{array}{l}\text { Linac } 4 \mathrm{MV} \text { Xray } \\
27.5 \mathrm{~Gy} \\
\text { OK } 432: 33.2 \mathrm{KE}\end{array}$ & 2 & $\begin{array}{l}\text { TIL: } 0.26 \times 10^{6} \\
(0.65 \mathrm{~g}) \\
\text { LN-TIL: } \\
2.56 \times 10^{6} \\
(0.4 \mathrm{~g})\end{array}$ & 14.6 & $\begin{array}{l}1.43 \times 10^{9}(28) \\
6.91 \times 10^{9}(28)\end{array}$ & $\begin{array}{l}28 \text { (凍結保存) } \\
28 \text { (凍結保存) }\end{array}$ \\
\hline 22. & $63 \mathrm{M}$ & $\begin{array}{l}\text { 口蓋 } \\
\text { Malignant } \\
\text { Melanoma }\end{array}$ & 施行せず & 3 & $\begin{array}{l}\text { TIL: } 0.44 \times 10^{6} \\
(0.15 \mathrm{~g})\end{array}$ & 0.7 & $2.80 \times 10^{9}(30)$ & 37 (測定） \\
\hline 23. & $60 \mathrm{M}$ & $\begin{array}{l}\text { 舌 } \mathrm{SCC} \\
(\mathrm{T} 4 \mathrm{~N} 2 \mathrm{aM0} \text { IV })\end{array}$ & $\begin{array}{l}\text { Tele }{ }^{60} \mathrm{Co} \\
30 \mathrm{~Gy}\end{array}$ & 3 & $\begin{array}{l}\text { TIL: } 3.30 \times 10^{6} \\
\text { (0.5 g) } \\
\text { LN-TIL: } \\
3.21 \times 10^{6} \\
(0.3 \mathrm{~g})\end{array}$ & $\begin{array}{r}1.4 \\
\mathrm{ND}^{2)}\end{array}$ & $\begin{array}{l}1.00 \times 10^{9}(28) \\
7.22 \times 10^{8}(28)\end{array}$ & $\begin{array}{l}40 \text { (測定） } \\
35 \text { (測定） }\end{array}$ \\
\hline 24. & $67 \mathrm{M}$ & $\begin{array}{l}\text { 口底 SCC } \\
(\mathrm{T} 4 \mathrm{~N} 0 \mathrm{M} 0 \mathrm{IV})\end{array}$ & 施行せず & $\mathrm{ND}^{1)}$ & $\begin{array}{l}\text { TIL: } 0.46 \times 10^{6} \\
(0.3 \mathrm{~g})\end{array}$ & 7. 6 & 増殖せず & 14 （測定） \\
\hline 25. & $46 \mathrm{M}$ & $\begin{array}{l}\text { 上顎歯肉 } \mathrm{SCC} \\
(\mathrm{T} 4 \mathrm{~N} 1 \mathrm{M} 0 \mathrm{IV})\end{array}$ & $\begin{array}{l}\text { Linac } 4 \mathrm{MV} \text { Xray } \\
42.5 \mathrm{~Gy} \\
\text { 5FU: } 2,000 \mathrm{mg} \\
\text { LAK 療法 i.a.* }\end{array}$ & 1 & $\begin{array}{l}\text { TIL: } 1.94 \times 10^{6} \\
(1.0 \mathrm{~g}) \\
\text { LN-TIL: } \\
44.25 \times 10^{6} \\
(1.8 \mathrm{~g})\end{array}$ & $\begin{array}{r}0.5 \\
16.9\end{array}$ & $\begin{array}{l}9.70 \times 10^{7}(9) \\
7.96 \times 10^{9}(18)\end{array}$ & $\begin{array}{l}10 \text { (細菌沫染) } \\
18 \text { (細胞移入) }\end{array}$ \\
\hline 26. & $69 \mathrm{~F}$ & $\begin{array}{l}\text { 口蓋 Adenoid } \\
\text { Cystic Ca } \\
(\mathrm{T} 4 \mathrm{~N} 0 \mathrm{M} 0 \mathrm{~V})\end{array}$ & LAK 療法 i.a. & 1 & $\begin{array}{l}\text { TIL: } 0.23 \times 10^{6} \\
(0.2 \mathrm{~g})\end{array}$ & ND & $6.87 \times 10^{7}(19)$ & 19 (細胞移入) \\
\hline 27. & $67 \mathrm{M}$ & $\begin{array}{c}\text { 上顎洞 } \mathrm{SCC} \\
(\mathrm{T} 4 \mathrm{~N} 2 \mathrm{bM} 0 \mathrm{IV})\end{array}$ & $\begin{array}{l}\text { Linac } 4 \mathrm{MV} \text { Xray } \\
\text { 25Gy } \\
\text { LAK 療法 i.a. }\end{array}$ & 1 & $\begin{array}{l}\text { TIL: } 0.41 \times 10^{6} \\
(0.5 \mathrm{~g}) \\
\text { LN-TIL: } \\
6.72 \times 10^{6} \\
(0.4 \mathrm{~g}) \\
\text { LN-TIL**: } \\
16.1 \times 10^{6} \\
(1.7 \mathrm{~g})\end{array}$ & $\begin{array}{r}4.8 \\
12.6 \\
15.5\end{array}$ & $\begin{array}{l}\text { 増殖せず } \\
6.29 \times 10^{8}(17) \\
8.98 \times 10^{8}(18)\end{array}$ & $\begin{array}{r}\text { (細菌污染) } \\
17 \text { (細胞移入) } \\
18 \text { (細胞移入) }\end{array}$ \\
\hline 28. & $81 \mathrm{M}$ & $\begin{array}{l}\text { 口蓋 } \\
\text { Malignant } \\
\text { Melanoma }\end{array}$ & OK432: 15KE & 2 & $\begin{array}{l}\text { TIL: } 0.67 \times 10^{6} \\
(0.1 \mathrm{~g}) \\
\text { LN-TIL: } \\
7.5 \times 10^{6} \\
(1.1 \mathrm{~g})\end{array}$ & $\begin{array}{l}\text { ND } \\
3.8\end{array}$ & $\begin{array}{l}6.90 \times 10^{6}(14) \\
3.13 \times 10^{8}(14)\end{array}$ & $\begin{array}{l}14 \text { (凍結保存) } \\
14 \text { (凍結保存) }\end{array}$ \\
\hline
\end{tabular}

培湌可能日数でのカッコ内は, 培㽰中止理由を示す.

*: 経動脈的投与, **：2 回目の手術で得られた検体, ND ${ }^{1)}:$ LI-grade の確認されていない検体, $\mathrm{ND}^{2)}$ : 腫瘍 細胞が不明瞭で $\mathrm{L} / \mathrm{T}$ 比が算出不能な検体.

浮遊させ, Türk 液染色によりリンパ球数を算出したも のを PBL とした.

培養液として, $10 \%$ ヒト $\mathrm{AB}^{+}$血清, $100 \mathrm{U} / \mathrm{ml}$ ペニ シリン $\mathrm{G}$ カウム（明治), $100 \mu \mathrm{g} / \mathrm{m} l$ 硫酸ストレプト マイシン（明治）を含む RPMI 1640 培地（日水製薬） および $5 \%$ ヒト $\mathrm{AB}^{+}$血漿を含む HyMedium 910 ( ージンバイオ社）を CM とした。 ヒト血清および新鮮 凍結血漿から融解された血漿は， $56^{\circ} \mathrm{C}$ で 30 分間非働化 して使用した。

2) 腫瘍組織浸潤リンパ球 (TIL) および腫瘍転移り ンパ節リンパ球 (LN-TIL) の分離

TIL は, 手術切除標本の 腫瘍組織塊をはさみで細切 後, 酵素処理 (collagenase Type V-S (SIGMA) 2mg/ ml, DNAse-I Type II (SIGMA) $0.002 \%$, Hyaluronidase Type VI-S (SIGMA) $100 \mathrm{u} / \mathrm{ml}$ を含む培養液中 で, $37^{\circ} \mathrm{C}$ で 90 分から 3 時間旋回培養器中で振とう）を 行い組織を融解し, ナイロンメッシュ (200 mesh) を通 過させ, PBL の分離と同様に比重遠心法で分離し培養 液中に浮遊させた.

LN-TIL は, 手術切除標本より肉眼的に腫瘍転移の 認められたリンパ節を採取し, 少量の培養液を加えハサ ミで細切後ナイロンメッシュ(200 mesh) を通過させ, PBL と同様の方法で分離した。

培養液中に浮遊された細胞は, トリパンブルーによる dye exclusion test で, リンパ球の生細胞数扣よびリン パ球腫瘍細胞比が算出された. 


\section{4. 新鮮腫湟細胞の分離・保存}

TIL，LN-TIL の分離時に同一の腫瘍組織塊より新鮮 腫瘍細胞を分離した．分離法は上記の TIL と同様の方 法で行い，最終的に比重遠心をせずに洗浄し，培養液に 浮遊させた。凍結用培養液 $\left(90 \% \mathrm{HI}\right.$. $\mathrm{AB}^{+}$Human Serum, 10\% Dymethl sulfoxide (DMSO): SIGMA) に浮遊させ, 液体窒素中で涷結保存し, 測定時に融解 し，自己新鮮腫瘍細胞として標的細胞に用いた。

\section{5. リンパ球の培養, 保存}

リンパ球を $5 \sim 6.25 \times 10^{5}$ 個 $/ \mathrm{m} l$ に調整し, $140 \sim 350$ $\mathrm{JRU} / \mathrm{m} l$ の IL-2 を含む $\mathrm{CM}$ 中で $5 \% \mathrm{CO}_{2}, 37^{\circ} \mathrm{C}$ 条 件下で培養し，IL-2 活性化細胞を誘導した.

また, 培養初期に $10 \mu \mathrm{g} / \mathrm{ml}$ の抗 CD3 抗体（人体投 与用 OKT3 製剤：ヤンセン協和）で固相化したプレー トを用い, $700 \mathrm{JRU} / \mathrm{m} l$ の $\mathrm{IL}-2$ を含む $\mathrm{CM}$ 中で培養 し抗 CD3 抗体/IL-2 活性化細胞を誘導した.

リンパ球の培湌開始は, 96 穴平底プレート (NUNCL ON）を用いた。培養されたリンパ球の一部は, 凍結用 培養液 (90\% HI. $\mathrm{AB}^{+}$Human Serum, 10\% DMSO) に浮遊させ, 液体窒素中で涷結保存した。 必要に応じて 細胞融解後 $700 \mathrm{JRU} / \mathrm{ml}$ の IL-2 を含む $10 \% \mathrm{AB}^{+} \mathrm{HS}$. RPMI 1640 培地で 4 日間培養後測定に供した.

\section{6. 細胞增殖能の測定}

培養期間中, 経時的に培養リンパ球の一部を採取し, トリパンブルーによる dye exclusion test 抌よびリンパ 球数の算出を行った. 培養リンパ球の増殖曲線を描記 し, それぞれの細胞の最大増殖率および細胞数が最大に 達するまでの日数および最大獲得細胞数を算出した。 た，TILの IL-2に対する細胞増殖反応を ${ }^{3} \mathrm{H}$-thymidine (TdR) の取り込み量によって測定した.すなわち，96 ウエル平底プレート（Falcon 3042）を使用し, 細胞を $2 \times 10^{4}$ 個 $/ 200 \mu \mathrm{l} /$ ウェルに分注し，0，7，70，700 JRU/ $\mathrm{m} l$ の各濃度の IL-2 で 3 日間培養し, 収穕 18時間前に ${ }^{3} \mathrm{H}-\mathrm{TdR}$ (New England Nuclear, Specific Activity 5.0 $\mathrm{Ci} / \mathrm{mmol}$ に調整) を $0.5 \mu \mathrm{Ci}$ ずつ各ウェルに滴下し, 培養終了後セルハーベスター（Titertek）で収穫し細胞 内に取り込まれた ${ }^{3} \mathrm{H}-\mathrm{TdR}$ を液体シンチレーションカ ウンター（パッカード460 C) で測定した.

\section{7. 樹立細胞株の培養}

K 562 (慢性骨髄性白血病由来細胞株) 扎よび Daudi (パーキットリンパ腫由来細胞株)細胞は，10\%HI. FCS 加 RPMI 1640 培地で培養維持された。 NA（舌扁平上 皮癌由来細胞株), OM-1 (舌扁平上皮癌由来細胞株：症 例 8 ）抽よび RS-1（上顎洞横紋筋肉腫由来細胞株：症 例12) 細胞は, 10\% HI. FCS 加 DMEM 培地(SIGMA) で培養維持された。

\section{8. 細胞障害活性の測定}

細胞障害活性の測定は, 4 時間の ${ }^{51} \mathrm{Cr}$ 遊離試験法で行 った. NK 活性の測定には NK 感受性細胞株である K
562を, LAK 活性の測定には NK 非感受性細胞株であ る Daudi 扣よび NA を標的 (Target) 細胞として用い た。さらに自己腫瘍細胞に対する細胞障害活性を測定す るために, 培養腫瘍細胞株として OM-1, RS-1 を, 新 鮮腫瘍細胞として上顎洞横紋筋肉腫（症例12）およびロ 蓋覀性黒色腫（症例28）を標的細胞として用いた.

標的細胞は ${ }^{51} \mathrm{Cr}\left(\mathrm{Na}_{2}{ }^{51} \mathrm{CrO}_{4}\right.$, New England Nuclear) $3,700 \mathrm{KBq}$ を添加し， $37^{\circ} \mathrm{C}$ で 1 時間標識した後， 3 回 洗浄し $5 \times 10^{3}$ 個 $/ 0.1 \mathrm{ml} /$ well となるように 調整した. 単層培養細胞である NA， OM-1 および RS-1 について は, $0.1 \mathrm{mM}$ EDTA (同仁化学), $1,000 \mathrm{U} / \mathrm{m} l$ トリプ シン (持田製薬) を含むPBS で処理後, 単細胞浮遊液 として標識した.エフェクター (Effector) 細胞を種々の effector/target (E/T) 比となるように調整し $100 \mu l$ ず つ96穴U底プレート（住友マルチプレート）に撤き，そ の後標的細胞を加光全量 10\%HI. FCS 加 RPMI 1640 培地 $200 \mu \mathrm{l} /$ well とし, プレートを $200 \mathrm{G}, 60$ 秒間遠心 後, $5 \% \mathrm{CO}_{2}, 37^{\circ} \mathrm{C}$ で 4 時間反応させた.

反応終了後, 培養上清を $100 \mu l$ ずつ採取し, 上清中に 放出された ${ }^{51} \mathrm{Cr}$ の放射活性をガンマーシンチレーショ ンカウンター（パッカード800C）にて測定した.

細胞障害活性（\%lysis）は次式で計算した。

細胞障害活性 (\%lysis) = 実験遊離 (experimental release) 一自然遊離 (spontaneous release)/最大遊離 (maximum release) 一自然遊離 (spontaneous release) $\times 100$

最大遊離は標的細胞を20\% triton X (Sigma) を含む PBS で溶解したもの，自然遊離は標的細胞のみを培養 したものの計測値である.

Lytic unit (LU) ${ }^{22)}$ は, $5 \times 10^{3}$ 個の標的細胞の $33.3 \%$ を障害するエフェクター細胞数を $1 \mathrm{LU}$ と表し， LU/1 $\times 10^{6}$ を計算で求めて表示した。

\section{研 究 結 果}

\section{1. 腫瘍組織浸潤リンパ球 (TIL) および腫瘍転移リン} パ節リンパ球（LN-TIL）の分離結果（表 1，2）

検索症例28例 (34検体) のちち, TIL, LN-TIL が増 殖したものは, 分離直後に TIL としてすべて細胞障害 活性の測定に用いたもの 4 検体（症例11，13，14，19： TIL）を除いて 25 検体で，全体の $83 \%$ （25/30 検体）で あった，増殖しなかったものの内訳は，分離後に細菌污 染を起こし増殖率の測定できなかったものが 1 検体（症 例 $27: \mathrm{TIL}$ ), 分離後増殖しなかったものが 4 検体（症 例6，7，18，24すべて TIL) であった.

まず TIL の回収率(腫瘍組織 $1 \mathrm{~g}$ 当りのリンパ球数) を算出し, 原発腫瘍の組織型, 術前治療の有無おょび LI grade との関係を検討した（図1）。その結果，原発 腫瘍組織型の検討では扁平上皮癌の TIL の回収率は横 


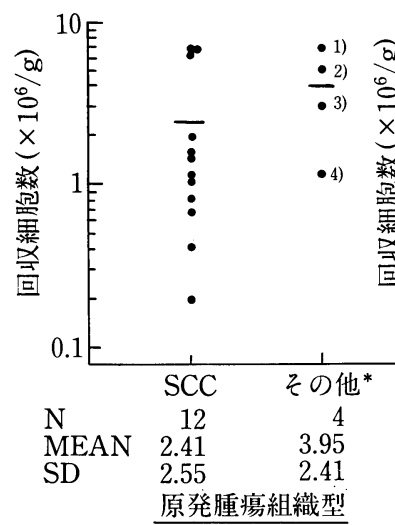

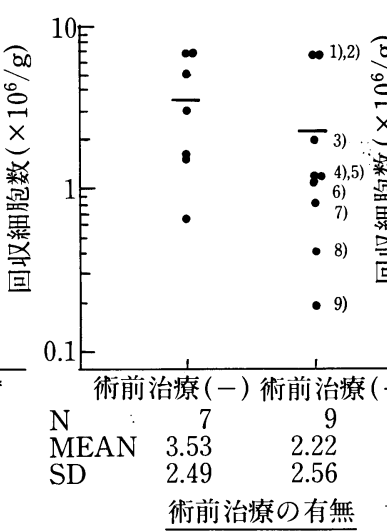

2)横紋筋内腫 (症例12) 4) 症例10:化学療法

3) 悪性黒色腫 (症例22) 2) 症例 28,5 ) 症例 26

4) 腺椂囊胞癌 (症例 26) 3) 症例 25,7 ) 症例 27,8$)$ 症例 21 :放射線 +免疫療法

図 1 原発腫瘍組織型, 術前治療の有無拉よび LI grade そ TIL の回収細胞数との関係.

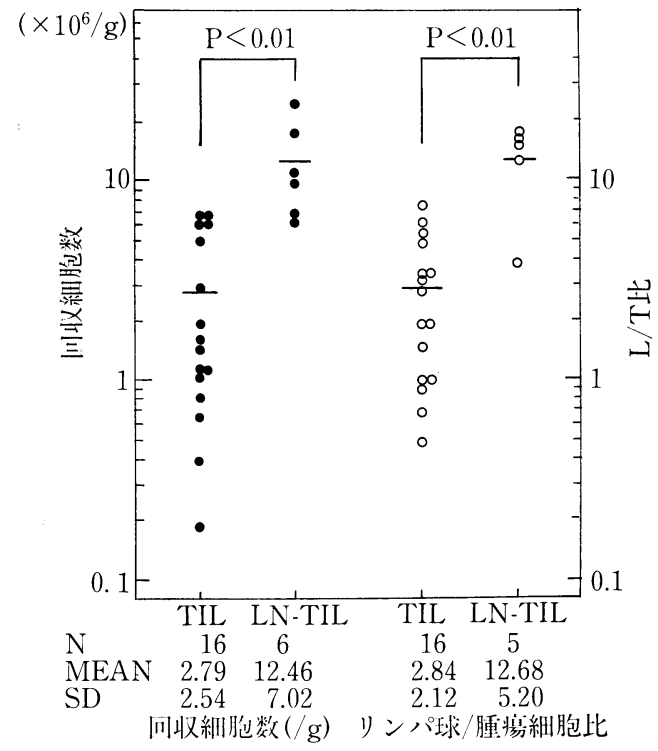

図 2 TIL および LN-TIL の回収細胞数ならび にリンパ球/腫瘍細胞比 ( $\mathrm{L} / \mathrm{T}$ 比).

紋笳肉腫, 悪性黑色腫に比べて低い傾向であった，術前 治療の有無では, 術前治療の施行されていない群で回収 率は高い傾向であった。ささらに術前治療として施行され た放射線療法, 化学療法, LAK 細胞による養子免疫療 法，IL-2の腫瘍局所投与および OK432 の皮内投与など の免疫療法, 放射線十免疫療法の間で, 回収細胞数との 関連性は認められなかった。原発腫瘍の LI grade では, grade の高いほど TIL の回収率が高くなる傾向であっ た.
さらに回収細胞中の腫瘍細胞の混入率を比較する意味 で, TIL と LN-TIL の回収率およびリンパ球/腫瘍細 胞比（L/T 比）を算出し比較した（図 2). その結果, 回収率の比較では, TIL では0.19 $\times 10^{6}$ 個 $/ \mathrm{g} \sim 6.70 \times 10^{6}$ 個 $/ \mathrm{g}$ で平均 $2.79 \pm 2.54 \times 10^{6}$ 個 $/ \mathrm{g}, \mathrm{LN}-\mathrm{TIL}$ では 6.40 $\times 10^{6}$ 個 $/ \mathrm{g} \sim 24.58 \times 10^{6}$ 個 $/ \mathrm{g}$ で, 平均 $12.46 \pm 7.02 \times 10^{6}$ 個/g であった. L/T 比の比較では, TIL では0.5〜7.6 で平均 $2.84 \pm 2.12$, LN-TIL では3.8〜16.9で平均 12.68 土5.20であった。回収率, L/T 比ともに TIL と LNTIL との間に有意差が認められた。

\section{IL-2 で培養中の TIL の細胞増殖能と細胞障害活 性}

1) 細胞数の推移と培養日数

IL-2 単独培養による TIL の細胞増殖能を観察した (図3). その結果, 最大増殖率は, TIL が PBL よりも 高く, PBL では1.4 84.3倍で平均22.6土23.9倍であっ たのに対し，TIL では 3.7〜890倍で平均 127.8土272.5 倍であった。ここでは有意差はみられなかったが, PBL と比較して TIL の優れた増殖能が観察された. 細胞数 が最大に達するまでの培養日数は，TIL では 9～56日で 平均23.1土12.7日で, PBL は8〜39日で平均 $22.3 \pm 10.1$ 日であり，両者ともほぼ同様であった。 TIL の最大増 殖率が PBL を上回った症例は， 6 例（症例 1，2，9，

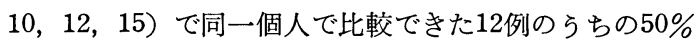
であった. TIL の最大獲得細胞数は, $2.18 \times 10^{6} \sim 3.56$ $\times 10^{9}$ の範囲で, 平均 $3.17 \times 10^{7}$ 個であった（表 1 ）.

さらに, TIL の IL-2 に対する反応性を PBL と比較 検討するため, 最も高い増殖率を示した症例 12 につい て, 増殖反応を異なった濃度の IL-2 で培養し経時的に 測定した（表了）. 


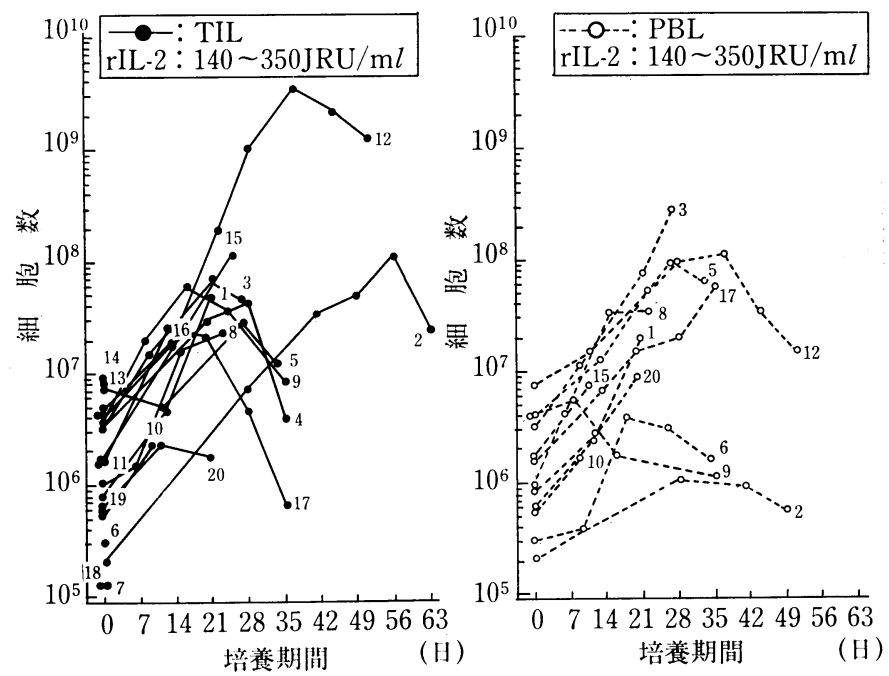

図 3 IL-2 活性化 TIL おょび PBL (LAK) の細胞増殖能. 図中の数字は症例番号を示す.

表 3 TIL の IL-2 に対する増殖反応

\begin{tabular}{c|c|c|c|c|c}
\hline & \multirow{2}{*}{\begin{tabular}{c} 
IL-2 濃度 \\
\cline { 3 - 6 } 培盖日教
\end{tabular}} & \multicolumn{5}{|c}{${ }^{3} \mathrm{H}-\mathrm{TdR}$ 取り込み量 $(\mathrm{CPM})$} \\
\cline { 3 - 6 } 13日目 & TIL & 0 & 7 & 70 & $700(\mathrm{JRU} / \mathrm{m} l)$ \\
\hline \multirow{2}{*}{22 日目 } & PBL & $538.9 \pm 52.2$ & $24,515.8 \pm 409.7$ & $\mathrm{NT}$ & $29,438.3 \pm 778.8$ \\
& TIL & $144.8 \pm 55.4$ & $9,583.2 \pm 420.6$ & $25,185.6 \pm 693.0$ & $33,554.7 \pm 698.2$ \\
& PBL & $3,014.4 \pm 246.0$ & $12,708.4 \pm 489.8$ & $14,120.5 \pm 702.5$ & $14,413.8 \pm 76.5$ \\
\hline \multirow{2}{*}{28 日目 } & TIL & $113.7 \pm 59.7$ & $1,754.0 \pm 122.7$ & $5,513.8 \pm 222.1$ & $8,129.7 \pm 230.8$ \\
& PBL & $247.8 \pm 30.0$ & $6,201.0 \pm 277.9$ & $7,230.3 \pm 199.4$ & $8,066.3 \pm 434.9$ \\
\hline
\end{tabular}

症例12に拈いて, $350 \mathrm{JRU} / \mathrm{m} l$ の $\mathrm{rIL}-2$ で培養中の $\mathrm{TIL}$ おょび $\mathrm{PBL}$ の，培盖13，22おょび28日目の rIL-2 に 対する増殖反応をそれぞれ 3 日間の培㽰で ${ }^{3} \mathrm{H}-\mathrm{TdR}$ の取り込み量 (CPM) を測定し比較検討した.

${ }^{3} \mathrm{H}-\mathrm{TdR}$ の取り込み量 (CPM) はそれぞれ triplicate で測定した值を MEAN土SE で表示した.

その結果，長期間培養された TIL は低濃度の IL-2 には反応しつららなるが，その反応性は濃度依存性に増 強された。この反応態度は，同一個人の PBL でも同様 の傾向がみられたが, TILに扎いて著明であった。 この ことより, TIL は IL-2 濃度依存性に PBL より効率よ く増殖することが示された。

2) TIL の細胞障害活性 (NK および LAK 活性) の経時的変化

標的細胞として NK 活性の測定に K562 を, LAK 活 性の測定には NA を用いて，4 時間の ${ }^{51} \mathrm{Cr}$ release assay 法で細胞障害活性を測定し，TIL および PBL の NK および LAK 活性の経時的な変化を観察した（図 4). その結果，IL-2 で培养することにより TIL から NK
活性の増強および LAK 活性の出現が認められた。 とく に培養 3 週目以降では TIL の NK, LAK 両活性は PBL のそれを上回るようになり，その活性は 8 週目以 降まで維持された，NK 扎よび LAK 活性がピークに 達する時期は, TIL では培養 3 週, PBL では培養 2 週 で, TIL が PBL よりも遅れる傾向であった。

\section{IL-2 の腫瘍局所投与による TIL の細胞障害活性 （NK および LAK 活性）の誘導}

術前治療として腫瘍切除の前に IL-2 の局所投与を行 った症例の切除標本より TIL を分離し, 分離回収直後 の新鮮 TIL の NK および LAK 活性を測定し, IL-2 非投与症例と比較検討を行った（図 5). IL-2 非投与例 の新鮮 TIL は, NK および LAK 活性がほとんど認め 
られず，PBL と比較して特に NK 活性は抑制されてい た. 一方，IL-2 局所投与例の新鮮 TIL では, PBL と ともに NK 活性の増強および LAK 活性の出現が認め られ，PBL よりも高值を示す症例もみられた. PBL の $\mathrm{NK}$ 活性にのみ, IL-2 投与例と非投与例で有意差が認 められたが $(\mathrm{P}<0.01) ， \mathrm{TIL}$ では両者間に 有意差は認 められなかった． IL-2 局所投与例の TIL の細胞障害活 性は，症例によりかなりばらつきがみられた。 とくに症

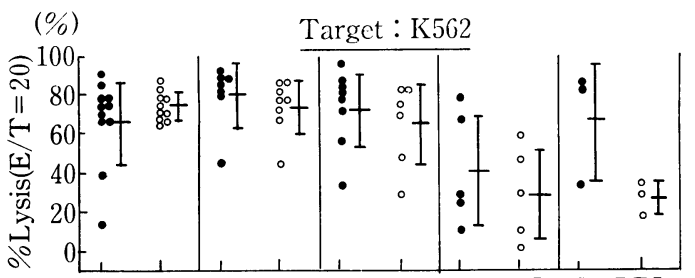

$\underset{\leq 2}{\text { TIL PBL TIL PBL TIL PBL TIL PBL TIL PBL }} \underset{\leq 3 \text { 週 }}{ }$

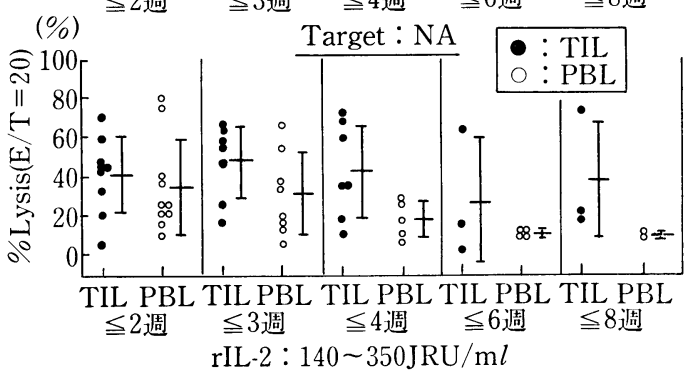

図 4 IL-2 活性化 TIL および PBL (LAK) の細 胞障害活性の経時的変化.
例16のように TIL の NK 活性が78.8\%と, PBL より も高值を示寸症例もあれば, 症例 14 の TIL のように NK および LAK 活性ともにほとんど示さない症例が確 認された。ここでは特に IL-2 の局所投与量との関連性 はなかった。

4. 抗 CD3 抗体/IL-2 で培竟中の TIL および LNTIL の細胞增殖能と細胞障害活性

1 ) 細胞数の推移と培養日数

固相化抗 CD3 抗体および IL-2 の培養による TIL および LN-TIL の細胞増殖能を観察した（図 6). その 結果, 最大増殖率は，TIL，LN-TIL，PBL でそれぞれ 平均 $2,091.6 \pm 2,998.1$ 倍, 549.4土1, 056.0 倍, 3,671.3 $\pm 3,487.7$ 倍を示し，それぞれ IL-2 単独で培養した場 合と比較して数十倍から数百倍上回る值であった. 細胞 数が最大に達するまでの日数は，TIL, LN-TIL， PBL でそれぞれ平均 $21.3 \pm 8.7$ 日，20.5土6.0 日，23.4土6.5 日であり，IL-2 単独で培養した症例と差異はなかった。 TIL および LN-TIL の最大獲得細胞数は, TIL では $6.90 \times 10^{6} \sim 2.80 \times 10^{9}$ の範囲で平均 $9.00 \times 10^{8}$ 個, LNTIL では $3.13 \times 10^{8} \sim 7.96 \times 10^{9}$ の範囲で平均 $2.90 \times 10^{9}$ 個であった（表 2 ）.

2) TIL および LN-TIL の細胞障害活性 (NK お よび LAK 活性) の経時的変化

固相化抗 CD3 抗体および IL-2 で培養することによ り TIL, LN-TIL から NK 活性の増強および LAK 活性の出現が認められた（図 7)。NK および LAK 活 性がピークに達する時期は，平均で PBL では培養 2 週 であるのに対し TIL，LN-TIL では培養 3 週であった。

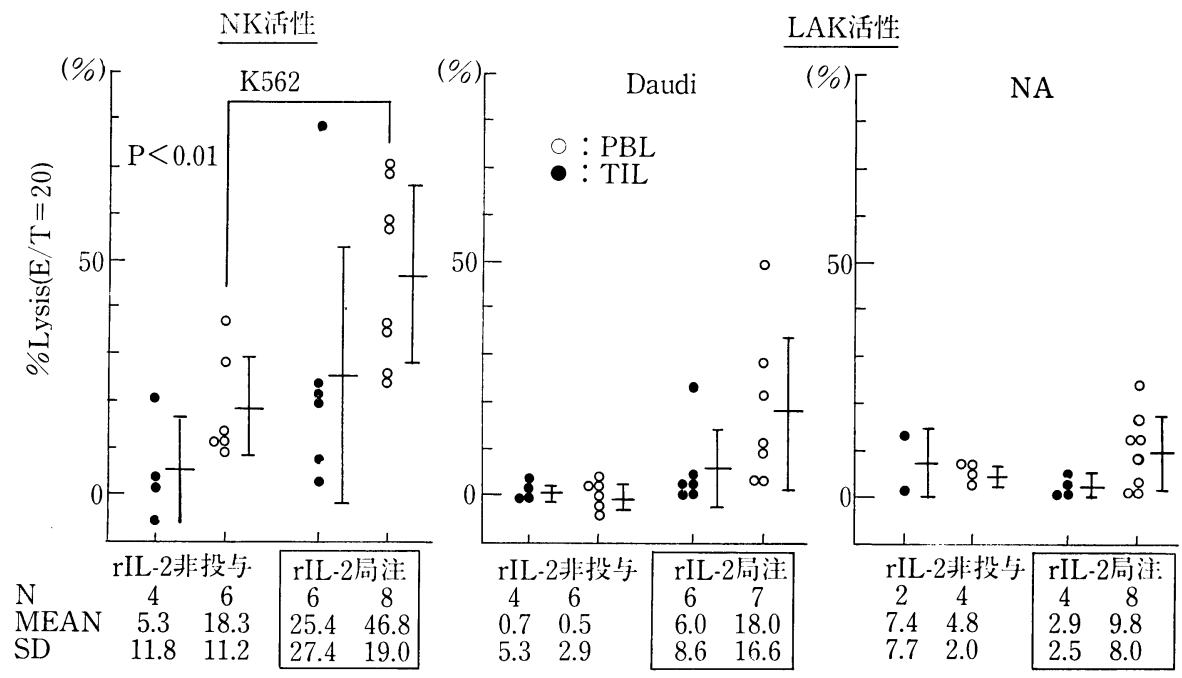

rIL-2局注拉例：rIL-2 8.4 29.4 × $10^{6}$ JRUhiu注

図 5 IL-2 の腫瘍局所投与による新鮮 TIL の NK おょび LAK 活性の增強. 

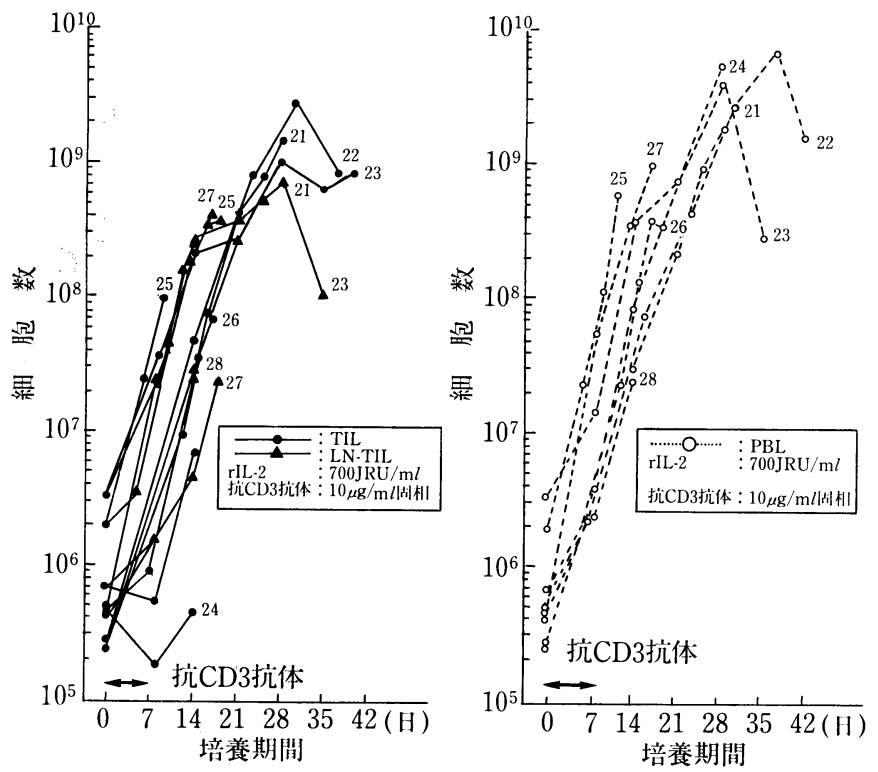

図 6 抗 CD3 抗体/IL-2 活性化 TIL, LN-TIL 拉よび PBL (CD3・LAK) の細胞增殖能。

図中の数字は症例番号を示す。
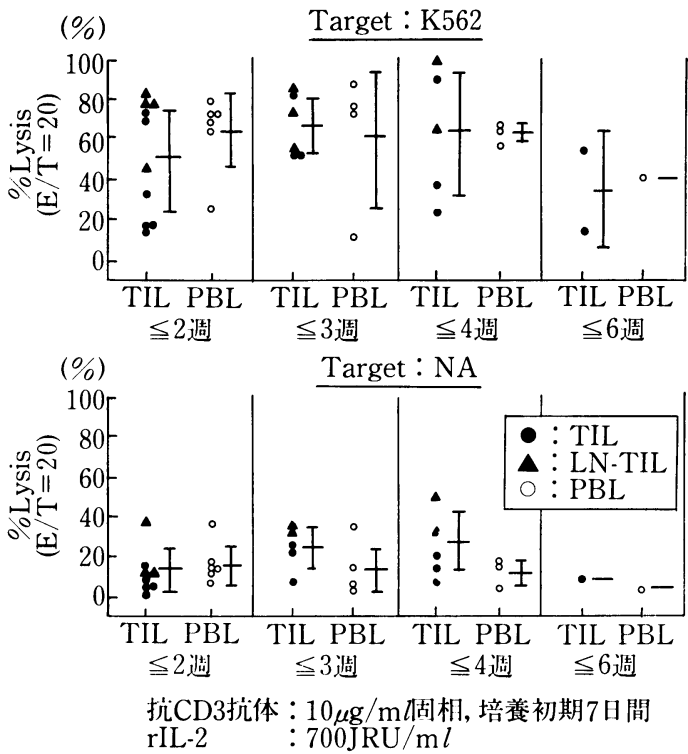

図 7 抗 CD3 抗体/IL-2 活性化 TIL, LN-TIL 拉 よび PBL (CD3・LAK) の細胞障害活性の 経時的変化.

TIL, LN-TIL と PBL の NK および LAK 活性值の 平均はほぼ同程度であったが, TIL, LN-TIL の群で高 いNK および LAK 活性が維持される症例が認められ
た.

5. IL-2 あるいは抗 GD3 抗体/IL-2 活性化 TIL お よび LN-TIL の自己腫瑒細胞に対する細胞障害活 性

1）自己培養腫瘍細胞株に対する TIL の細胞障害活 性

自己培養腫瘍細胞株が樹立された症例 8 (扁平上皮癌) と症例12 (横紋筋肉腫) そついて, 自己培養腫瘍細胞に 対する IL-2 活性化 TIL の細胞障害活性を検討した。 IL-2 活性化 TIL 拉よび PBL (LAK) はともに凍結融 解した後培養 4 日目の細胞を用いた（表 4 ）.

その結果, 症例 8 飞打いては, 培養23日目の TIL は K562 に対する細胞障害活性を示すのみで, 自己培養腫 瘍細胞 (OM-1) をはじめ他の培養腫瘍細胞飞対する細 胞障害活性は認められなかった。一方, 症例12の培養 13 日目特よび28日目の TIL は K562 亿対する高い細胞障 害活性を示すとともに, 自己培養腫瘍細胞 (RS-1) 飞対 して同種の培養腫瘍細胞より高い細胞障害活性を示した (表 5 ).

これと比較して, 症例 8, 症例12ともに PBL (LAK) は自己培養腫瘍細胞に対してまったく細胞障害活性を示 さなかった。

2）自己新鮮腫瘍細胞に対する TIL および LN-TIL の細胞障害活性

分離直後に凍結保存された自己新鮮腫瘍細胞に対する IL-2 活性化 TIL の細胞障害活性は症例 12 （横紋筋肉 
表 4 凍結融解細胞の細胞增殖率および Viability

\begin{tabular}{l|l|c|c|c}
\hline & IL-2 活性化細胞 & $\begin{array}{c}\text { 回収細胞数 (/g) } \\
\text { (Viability\%) }\end{array}$ & $\begin{array}{c}\text { 細胞増殖率(倍) } \\
\text { (日間) }\end{array}$ & Viability(\%) \\
\hline 症例 8. & PBL (Day 23) & $6.40 \times 10^{6}(73.4)$ & 0.49 & 95.1 \\
& TIL & $8.85 \times 10^{6}(80.0)$ & 0.69 & 95.2 \\
& PBL (Day 13) & $0.94 \times 10^{6}(17.8)$ & 0.34 & 96.7 \\
& TIL & $2.22 \times 10^{6}(44.4)$ & 2.01 & 94.9 \\
& TIL (Day 28) & $28.65 \times 10^{6}(90.3)$ & 0.21 & 95.3 \\
\hline
\end{tabular}

融解後のリンパ球は $700 \mathrm{JRU} / \mathrm{m} l$ の IL-2 で 4 日間培養され, 細胞障害活性の測定に供 した。

4 日間培養後のリンパ球の Viability は, TIL, PBL ともに良好であった.

表 5 IL-2 活性化 TIL の自己培養腫瘍細胞株に対する細胞障害活性（ 4 時間の ${ }^{51} \mathrm{Cr}$ 遊離試験）

\begin{tabular}{|c|c|c|c|c|c|c|c|c|c|}
\hline \multirow{3}{*}{$\begin{array}{l}\text { IL-2 } \\
\text { 活性化細胞 }\end{array}$} & \multirow{3}{*}{ 症 例 } & \multicolumn{8}{|c|}{ 標的細胞（細胞障害活性 : \% Lysis $\langle\mathrm{E} / \mathrm{T}=20\rangle$, Lytic units） } \\
\hline & & \multicolumn{2}{|c|}{ OM-1 } & \multicolumn{2}{|c|}{ RS-1 } & \multicolumn{2}{|c|}{ NA } & \multicolumn{2}{|c|}{ K562 } \\
\hline & & $\%$ Lysis & LU & $\%$ Lysis & LU & $\%$ Lysis & $\mathrm{LU}$ & $\%$ Lysis & LU \\
\hline \multirow[t]{3}{*}{ TIL } & $8(\mathrm{D}-23)$ & 6.5 & $\leq 0.01$ & 0.3 & $<0.01$ & 4.4 & $<0.01$ & 36.1 & 10.1 \\
\hline & $12(\mathrm{D}-13)$ & 45.7 & 20.2 & $\underline{54.4}$ & $\underline{64.1}$ & 48.6 & 19.8 & 69.7 & 704.1 \\
\hline & $(\mathrm{D}-28)$ & 75.7 & 33.4 & $\underline{72.1}$ & 84.4 & 77.0 & 45.2 & 78.9 & 3,387 \\
\hline \multirow{2}{*}{$\begin{array}{c}\text { PBL } \\
\text { (LAK 細胞) }\end{array}$} & $8(D-23)$ & 4.6 & $\leq 0.01$ & 1.7 & N.D & 3. 7 & $<0.01$ & 46.0 & 16.3 \\
\hline & $12(\mathrm{D}-13)$ & $\overline{\text { N.T }}$ & $\overline{N . T}$ & 1.7 & N.D & N.T & N.T & N.T & N.T \\
\hline
\end{tabular}

——自己培養腫瘍細胞に対する細胞障害活性を示す。

TIL および PBL は $350 \mathrm{JRU} / \mathrm{m} l$ の IL-2 で培養された。（）内は培養日数を示す。細胞障害活性の測定は，

融解後 4 日目に行われた.

N.D: $\mathrm{E} / \mathrm{T}=20$ のみ測定のため, LU は算出せず.

N.T: 測定せず.

表 6 活性化 TIL, LN-TIL おょび PBL の自己新鮮腫瘍細胞に対する細胞障害活性

\begin{tabular}{|c|c|c|c|c|c|c|c|c|c|c|}
\hline \multirow{3}{*}{ 症例 } & \multirow{3}{*}{ EFFECTOR 細胞* } & \multicolumn{9}{|c|}{ 標的細胞 (細胞障害活性 : \% Lysis $\langle\mathrm{E} / \mathrm{T}=20\rangle$, Lytic units(LU), total (LU) } \\
\hline & & \multicolumn{3}{|c|}{ 自己新鮮腫瘍細胞 } & \multicolumn{3}{|c|}{ NA } & \multicolumn{3}{|c|}{ K562 } \\
\hline & & $\%$ Lysis & LU & total LU & $\%$ Lysis & LU & total $\mathrm{LU}$ & $\%$ Lysis & LU & total LU \\
\hline \multirow[t]{2}{*}{12} & $(\mathrm{TIL}+\mathrm{IL}-2)_{13 \mathrm{~d}}$ & 24.1 & 3.7 & 69.0 & 46.4 & 19.2 & 3. $6 \times 10^{2}$ & 83.7 & 4. $0 \times 10^{3}$ & $7.4 \times 10^{4}$ \\
\hline & $(\mathrm{PBL}+\mathrm{IL}-2)_{13 \mathrm{~d}}$ & 12.8 & 0.7 & 8.7 & 39.9 & 14.5 & 1. $7 \times 10^{2}$ & 78.6 & 1. $0 \times 10^{2}$ & 1. $3 \times 10^{3}$ \\
\hline \multirow[t]{2}{*}{28} & $(\mathrm{LN}-\mathrm{TIL}+\mathrm{CD} 3 / \mathrm{IL}-2)_{14 \mathrm{~d}}$ & 20.1 & 3.1 & 87.4 & 11. 4 & 1.1 & 30.0 & 46.7 & 15.7 & $4.4 \times 10^{2}$ \\
\hline & $(\mathrm{PBL}+\mathrm{CD} 3 / \mathrm{IL} 2)_{14 \mathrm{~d}}$ & 10.9 & 0.1 & 3.0 & 13.0 & 1.0 & 24.0 & 66.4 & 34.9 & $8.6 \times 10^{2}$ \\
\hline
\end{tabular}

* 症例 12 は $350 \mathrm{JRU} / \mathrm{m} l$ の IL-2 単独で 13 日間培養された細胞, 症例 28 は $700 \mathrm{JRU} / \mathrm{m} l$ の $\mathrm{IL}-2$ と培養初期 7 日間固相化抗 CD3 抗体で刺激し，14日間培養された細胞を用いた。

腫) で, 抗 CD3 抗体/IL-2 活性化 LN-TIL の細胞障 害活性は症例28（悪性黑色腫）で検討した（表 6 ）.

その結果, 自己新鮮腫瘍細胞に 対して培養 13 日目の IL-2 活性化 TIL は, \%lysis で LAK の約 2 倍, 単位
細胞当りの細胞障害活性 (lytic units) では LAK の約 5 倍の細胞障害活性を示した。 また培養14日目の抗 CD3 抗体/IL-2 活性化 LN-TIL \& \%lysis で LAK の約 2 倍の, lytic units では LAK の約30倍の細胞障害活性を 
示した。 またこれらに増殖細胞数を加味した全細胞障 害活性 (Total lytic unit) で比較した場合, TIL およ び LN-TIL の自己新鮮腫瘍細胞に対する細胞障害活性 は, 自己の PBL よりも数段高い活性を示し, 自己腫瘍 細胞に対する細胞障害活性の選択性が示された。

\section{考察}

リンパ球をインターロイキン-2 (IL-2) で培湌して得 られる lymphokine-activated killer (LAK) 細胞は, NK 活性に抵抗性を示す新鮮固形腫瘍細胞に対して非特異的 な細胞障害活性を示すキラー細胞として1982 年 Grimm $ら^{8)}$ により定義された。癌に対する免疫療法の 1 つとし て, 近年, この LAK 細胞を用いた養子免疫療法が行わ れるようになり，他の治療法が無効であった進行癌症例 に対して有効であった症例も報告されている ${ }^{23)}$. またこ の養子免疫療法の効果を増強する目的で, LAK 細胞の 細胞障害活性を増強させるための培養法 ${ }^{11)}$ や投与法（投 与経路执よび併用療法としての投与のタイミング）の検 討 ${ }^{24,25)}$ が行われている.ささらに腫瘍組織に浸潤している ため, 腫瘍細胞を選択的に，あるいは特異的に障害する ことのできる可能性があると考えられるリンパ球を用い ることが考えられてきている.

そこで口腔悪性腫瘍患者から分離した TIL および LN-TIL の細胞障害活性や 細胞増殖能などの機能を検 索し, 口腔悪性腫瘍患者に対する養子免疫療法の移入細 胞としての有用性を検討することは有意義であると考え られる。

\section{TIL および LN-TIL の分離結果について}

本研究に拈いて, 検索対象の口腔原発悪性腫瘍組織 28 検体 (扁平上皮癌22例, 悪性黑色腫 2 例, 横紋笳肉腫, 骨肉腫, 粘表皮癌, 腺様囊胞癌がそれぞれ 1 例ずつ）打 よび転移リンパ節組織（扁平上皮癌 5 例, 覀性黒色腫 1 例） 6 例全例からリンパ球を分離回収することができ た.

リンパ球の回収率については, 当教室の杉山 ${ }^{26)}$ は酵素 処理を行わずに機械的方法でのみリンパ球を分離し， TIL では平均 $0.89 \times 10^{6}$ 個 $/ g$, LN-TIL では平均 22.62 $\times 10^{6}$ 個 $/ \mathrm{g}$ の細胞数を回収している. 今回酵素処理によ って分離された TIL の実験結果と比較すると, 酵素処 理をすることにより，TIL の回収細胞数の増加が 期待 できるものと考えられた。

細胞分離回収時のリンパ球腫瘍細胞比 ( $\mathrm{L} / \mathrm{T}$ 比) の検 討では，それぞれの検体では汪とんどが腫瘍細胞数を上 回る数のリンパ球が認められ, TIL では $0.5 \sim 7.6$ で平 均2.84土2.12であった。これは転移性メラノーマの症例 で $1.26 \pm 1.72^{27)}$ あるいは $0.40 \pm 0.37^{28)}$ ，腎細胞癌の症 例では1.87土1.04 29 あるいは腫瘍細胞混入率 $39.1 \pm 3.3$ $\%^{30)}$ などの報告例と比較してより高い数值であり，口腔
悪性腫瘍での TIL の浸潤度の高さがうかがわれた。さ らに LN-TIL の L/T 比は 3.8〜16.9 で平均 12.68土 5.20 であり, TIL との間に有意差がみられ転移リンパ 節組織では腫瘍細胞の混入率が低く, 効率よく LN-TIL が分離されることが示された。

TIL の回収細胞数に影響を及ぼす因子としては，特 に原発腫瘍組織型と LI-grade があげられ, TIL の回 収率は非上皮性腫瘍である横紋筋肉腫, 悪性黒色腫で高 く, LI-gradeの高い腫瘍で高い傾向が認められた。 LIgrade と TIL の回収率の関係については, 杉山到も同 様の結果を報告して拈り，組織標本上で単核細胞浸潤が 多く認められる腫瘍では, TIL の回収率は高い傾向が 示された。

\section{IL-2 単独培養による TIL の細胞增殖能および細 胞障害活性について}

今回の実験結果から IL-2 存在下での培養により, TIL の増殖率は PBL よりも数倍高いことが示された. Itoh ( $^{28)}$ は転移性メラノーマ, 肉腫および腎細胞癌から TIL を分離し, $140 \mathrm{JRU} / \mathrm{m} l$ の IL-2 存在下の培養で TIL の増殖率を測定し，その結果それぞれ $1,543 \pm 932$ 倍, $5,413 \pm 1,899$ 倍, $1,065 \pm 246$ 倍であり, 培養日数も 40日を越え, 今回口腔悪性腫瘍より分離された TIL と 比較して10倍以上の増殖率が認められている。中でも肉 腫からの TIL は他の 2 種の TIL と比べて最も高い増 殖率を示していた，今回 IL-2 単独で培養された 20 例の らち, 最も高い増殖率（890 倍，37日）を示した症例 12 は横紋筇肉腫であった。 頭頸部領域の腫瘍より分離され た TIL の報告 ${ }^{31,32)}$ ではそのほとんどが扁平上皮癌より 分離されたものであり, 増殖率は平均して 100 倍程度で あり PBL の増殖率より高い值を示していた.今回の結 果もこれらの報告例とほぼ同様の傾向であり, TIL の IL-2 に対する反応性は分離される 腫瘍組織型によって 異なる傾向が示唆された。

TIL の細胞障害活性については，IL-2 での培養によ り数日で NK 特よび LAK 活性を示すよらになる ${ }^{33)}$. この活性がピークに達するのは培養後 3 週目で, 培養 2 週目に活性のピークがある PBL と比較して遅れて出現 する傾向であった. この理由として, TIL では IL-2レ セプター (IL-2R) の発現がほとんどないこと ${ }^{34 \sim 36) や ， ~}$ 腫瘍細胞が IL-2 に対する反応性をはじめ PHA や ConA のようなマイトジェンに対する TIL の反応性を 抑制している可能性 ${ }^{35)}$ が考えられた。

一方，TIL には NK 細胞がほとんど観察されずT細 胞が優位であることが知られて扣り ${ }^{27,30,32,34,36)}$ ，このこ とより IL-2により活性化された TIL は heterogeneous ではあるが大部分でT細胞由来の LAK 活性を示してい る可能性も考えられた。 また当教室の東 ${ }^{37)}$ は LAK 前駆 細胞の検索で, PBL から NK 細胞分画 (Leu $4^{-1} 11^{+}$, Leu $4^{-} 7^{+}$) と T 細胞分画 (Leu $4^{+} 11^{-} 7^{-}$) からの LAK 
活性の誘導を行い, 短期培養（培養 7 日目）では NK 細 胞分画からの強い NK 执よび LAK 活性が認められ, 長期培養（培養 20 日目）により $\mathrm{T}$ 細胞分画からも NK および LAK 活性が認められるようになることを報告し て怙り, 今回の実験で, TIL の細胞障害活性が増強さ れる時期が同報告の $\mathrm{T}$ 細胞分画のものと同様の傾向を示 していた. ゆえにこれらの理由から，PBLから誘導され た LAK 細胞と比較して, TIL の細胞障害活性が遅れ て出現し長期間維持される現象は，IL-2 で活性化され た TIL がT細胞分画由来である可能性を示唆してい る.

\section{IL-2 の腫瘍局所投与による TIL の細胞障害活性 の誘導について}

先に述べたように腫瘍組織から分離された直後の新鮮

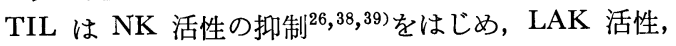
扎よび自己腫瘍細胞障害活性とも低いことが報告されて いる ${ }^{28,30,31,40 \sim 42)}$. また, TIL では IL-2R の発現はほと んどなく，IL-2 に対する反応性は抑制されているとの報 告 $^{34 \sim 36)}$ が多い。この理由として, サプレッサーT 細胞の 混在 ${ }^{27,43)}$, 腫瘍組織の産生する囚子によるサプレッサー $\mathrm{T}$ 細胞の活性化 ${ }^{44)}$ ，またこの因子による直接的な TIL の機能抑制 ${ }^{35)}$ などが考えられる. これに対して伊東ら ${ }^{45)}$ は, メラノーマ内の TIL の少なくとも一部は自己腫瘍 細胞を認識した CTL precursor もしくは immature CTL であり，腫瘍局所において IL-2 の供給が不十分 のために CTL precursor にとどまざるを得ないと推論 している.

今回の検索結果も諸家の報告と同様であり, 分離回収 直後の TIL の NK および LAK 活性はほとんど認め られなかった。しかし, 腫瘍切除前に IL-2 の局所投与 を行った症例では, 非投与例と比較して TIL の NK お よび LAK 活性は高い傾向を示した. さらに, IL-2 局 所投与例の 腫瘍では臨床的にも腫瘍縮小効果が認めら れ, 腫瘍局所には著しい炎症性細胞浸潤の出現がみら れ，その主体はリンパ球および形質細胞であった ${ }^{46,47)}$. このことより, in vivo に拈いて IL-2 の局所投与により TIL の細胞障害活性が増強されらることが示唆される とともに, TIL 中の 細胞障害性 $\mathrm{T}$ 細胞の 前駆細胞を, 腫瘍特異的あるいは非特異的な 細胞障害性 $\mathrm{T}$ 細胞へ分 化・増殖させる可能性をもつことも推測された ${ }^{41,48)}$.

\section{4. 抗 CD3 抗体/IL-2 での培養による TIL および} LN-TIL の細胞增殖能ならびに細胞障害活性につ いて

TIL 中の T 細胞をより選択的に増殖させる目的で抗 CD3 抗体を用いた実験を行い, 抗 CD3 抗体/IL-2 で 培養中の TIL の細胞増殖能と細胞障害活性について検 討し, 口腔覀性腫瘍者に対する養子免疫療法の移入細胞 として有用性について検討した.

$\mathrm{PBL}$ を 細胞レセプター複合体(TCR/CD3 complex)
に対するモノクロナール 抗体（抗 CD3 抗体）と IL-2 で刺激すると長期培養（14 日から 21 日）により，LAK 活性を維持したまま数百倍の細胞増殖が起こることが知 られている14,15)。 また TIL からも培養初期に固相化し た抗 CD3 抗体刺激により CD8 優位な T細胞が効率よ く増殖することが報告されている ${ }^{16,49)}$. さらに, 固相化 抗 CD3 抗体により TIL の IL-2R の発現率が増加す るとともに, IL-2 産生能も増強されることが報告され ている18)

今回の検索結果からは TIL, LN-TIL および PBL の ぞの細胞からも抗 CD3 抗体执よび IL-2 により細胞増 殖が認められその程度は，20日間から23日間でそれぞれ $2,091 \pm 2,998$ 倍, $549 \pm 1,056$ 倍, 3, 671 土3, 487 倍で, IL-2 単独培養の場合と比べて数十倍から数百倍上回る 増殖率であった。これは, IL-2 単独で培養した場合と 比較して，それぞれ PBL、では約160倍，TIL では約 16 倍の増殖率が増強されていた。 このことより, 抗 CD3 抗体の刺激により $\mathrm{T}$ 細胞表面の $\mathrm{IL}-2 \mathrm{R}$ の発現が増強さ れ，IL-2 に対する反応性が増大し，結果的に高い細胞 増殖能が観察されたものと考えられた.

細胞障害活性の経時的な変化では，PBL では NK お。 よび LAK 活性のピークが 2 週目であるのに対し，TIL LN-TIL では 3 週目であり, PBL より遅れて増殖する 傾向であった. とくに NK 活性は 4 週後でも非常に高 い活性を示していた。 この結果は, IL-2 単独で培養し た場合と同じであったが，前述した報告例のように，抗 CD3 抗体で刺激されていることから，この増殖してき た細胞は $\mathrm{T}$ 細胞優位と考えられ, 自己腫瘍細胞に対する 細胞障害活性を有する可能性が示唆された。実際に Pisani $^{50)}$ らは肺癌患者（非小細胞癌）から分離された TIL が抗 CD3 抗体と IL-2により活性化され自己新鮮 腫瘍細胞に対する細胞障害活性が増強され得ることを報 告している. そこで次に，IL-2 あるいは抗 CD3 抗体/ IL-2 活性化 TIL, LN-TIL の自己腫瘍細胞に対する細 胞障害活性について検討を行った.

\section{TIL および LN-TIL の自己腫瘍細胞に対する細} 胞障害活性について

自己培養腫瘍細胞に対する IL-2 活性化 TIL の細胞 障害活性については, 症例 8 の培養23日目で凍結保存さ れた IL-2 活性化 TIL は, NK 活性は温存されていた ものの, 自己腫瘍細胞障害活性を始め同種腫瘍細胞に対 する LAK 活性は消失していた. これは自己の PBL に 执いても同じ結果であった。一方, 症例12に打いては, 培養13日目および28日目で涷結保存された IL-2 活性化 TIL は両者ともに, 高い NK 活性を示すとともに, 他 の同種培養固型腫瘍細胞と比較して自己腫痬細胞に対す る選択的な細胞障害活性を示した。ここでは融解時の細 胞の生細胞率 (viability) や融解後の培養中の細胞増殖能 との関連性はみられなかった。 
TIL の自己腫瘍細胞に 対する 細胞障害活性の 検討で は腎癌由来の $\mathrm{TIL}^{28 \sim 30)}$ や, 頭頸部扁平上皮癌由来の TIL ${ }^{31,32)}$ に打いては, 必ずしも転移性メラノーマ腫瘍由 来の TIL ${ }^{27)}$ が示したような, 自己腫瘍特異的な細胞障 害活性を示しているとは限らない. しかし症例によって は自己腫瘍に選択的な活性を有する TIL も認められ, 由来する腫瘍組織のみでなく，個体によってもその性状 が異なることが考えられた。

自己新鮮腫瘍細胞に対する細胞障害活性については, 症例12は IL-2 単独培養, 症例28は抗 CD3 抗体/IL-2 培養であるが, 両者ともに活性化 TIL および LN-TIL は自己新鮮腫瘍細胞に対して障害活性を示した.つま り，症例12の培養13日目の TIL は K562 に対しては同 一条件で培養した自己の PBL と同様の NK 活性を示 す一方自己腫瘍に対しては PBL より高い值を示し, 症 例28では, 培養14日目の抗 CD3 抗体/IL-2 活性化 LNTIL は同一条件で培養した自己の PBL と比較して NK 活性が低いにもかかわらず, 自己新鮮腫瘍細胞に対して は数倍高い細胞障害活性を示し, 自己新鮮腫瘍細胞に対 する選択的な細胞障害活性が認められた。一方, PBL か ら IL-2により誘導された LAK 細胞の自己新鮮腫瘍細 胞に対する細胞障害活性の報告 ${ }^{51)}$ では，10例中 6 例に活 性が認められているが，この活性は同種の樹立腫瘍細胞 株（K562, NA，Daudi）に対しても細胞障害活性を有 する非特異的な細胞障害活性であった。

TIL のエフェクター細胞としての免疫細胞学的な位 置つけについて考察をしてみると, 癌細胞に対して障害 性をもつリンパ球は次の 3 つに分類することができ る52 54). すなわち, 1 ) Antigen-specific, MHC-restricted CTL, 2) Non-MHC restricted cytotoxic T lymphocytes，3) NK cells である.1) は細胞表面に発現 されている TCR/CD3 複合体によって標的細胞を認識 し障害し，それは MHC に拘束されている，2）は細胞 表面に TCR/CD3 複合体を発現しているが，その細胞 障害活性は MHC 非拘束である. 3) は TCR/CD3 複 合体が欠如して扣り細胞障害活性は MHC 非拘束性で あり, 細胞表面に CD16 あるいは NKH1 を発現して いる. われわれが PBL から抗 CD3 抗体/IL-2 で培養 して得られた CD3・LAK の細胞障害機序は TCR/CD3 複合体を介しているものと, NK 様の TCR/CD3 複合

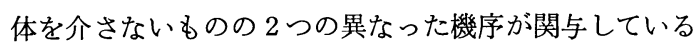
可能性のあることを報告した ${ }^{55)}$.

今回 TIL および LN-TII,を IL-2 あるいは抗 CD3 抗体/IL-2 で培養して得られた活性化細胞は, その細胞 障害活性は LAK 様であったが，自己腫瘍細胞に対する 選択性は PBL から活性化されたいわゆる LAK と比較 した場合にあきらかに強く認められた. 頭頸部以外の領 域では, 進展肺癌患者の胸水より得られたリンパ球 (TIL)の機能の検索や42), 産婦人科領域悪性腫瘍の TIL

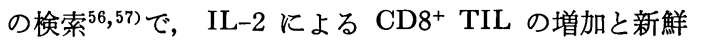
自己腫瘍細胞に対する細胞障害活性の増強が認められ, また腎細胞癌の TIL では ${ }^{58)} \mathrm{MHC}$ ク ラ ス 拘束性の CTL の誘導の可能性について報告されており, TILの 自己腫瘍細胞に対する細胞障害活性が認められている.

\section{TIL の臨床応用に際しての問題点}

このように TIL の養子免疫療法の移入細胞としての 有用性が示された反面, 実際に臨床応用にあたり次のよ らな問題点が残されている。

1）消化器の一種である口腔は体外と連絡を有する場 合が多く，常に細菌污染にさらされている.このため TIL の長期培養による細菌増殖の可能性が高い，2）す べての症例から TIL が得られるとは限らない，3）腫 瘍を混じた状態で TIL を培養するため, TIL に細胞障 害活性が誘導されない場合, 腫瘍細胞が細胞移入時に残 存する可能性がある.

以上の問題点に関して, 菅ら ${ }^{59)}$ は 1) に対しては消化 器癌, 乳癌原発巣からの TIL 使用の断念一所属りンパ 節リンパ球の積極的使用，3）に対しては, 培養系への TCGF の添加を行っている. われわれの今回の実験結 果からは, 分離・培養の過程で細菌污染を起こしたもの は 5 例あり, すべて口腔原発巣から得た TIL であり, LN-TIL で細菌污染を起こしたものは 1 例もなかった. また, 回収細胞数扣よび最大獲得細胞数からみても, LN-TILはより優れており, 積極的に LN-TILを使用 することが問題点 (1)，（2）の対策になるものと考えら れた.（3）については, Itoh ら ${ }^{28)}$ は $140 \mathrm{JRU} / \mathrm{m} l$ の IL-2 で培養中の melanoma の TIL 12例のうち 3 例に 腫瘍細胞の残存がみられたが，4週目までに消失したと 述べている。 また堀ら ${ }^{60)}$ も TCGF を用いた癌性胸水の 培養では全例 9 日目までに癌細胞が消失したことを報告 している.われわれの結果からも140～700 JRU $/ \mathrm{ml}$ の IL-2 存在下で TIL が増殖した症例では, トリパンブ ルー染色でみる限りでは, 少なくとも14日目までには腫 瘍細胞は消失していたが，今後実際に TIL を臨床応用 するに当たり詳細な検討が必要と思われた.

今後, 口腔悪性腫瘍患者に扣いて, TIL の標的細胞 認識についての検討を行いその性状をあさらかにすると

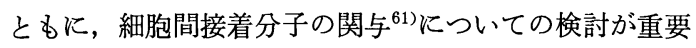
な課題と考えられる。 また, 実際に臨床投与した場合の 体内動態 ${ }^{62)}$ の検討や, 併用療法の検討など, 腫瘍集積性 の検討が TIL を用いた養子免疫療法を成功に導く要素 となるものと考えられた。

結語

口腔悪性腫瘍患者より尰瘍組織浸潤 リンパ 球を 分離 し, IL-2 による in vitro での細胞増殖能および細胞障 害活性の増強を試み, 抗腫瘍活性誘導の可能性について 
検討した。 また，術前治療として腫瘍切除前に腫瘍組織 周囲に IL-2 の局所投与を行い, 切除標本より分離され た新鮮 TIL の細胞障害活性 (NK および LAK 活性) を測定し，IL-2 の腫瘍局所投与による TIL の細胞障害 活性誘導について検討した。 さらに， $\mathrm{T}$ 細胞を選択的に 増殖させることを目的として，抗 CD3 抗体および IL-2 を用いて TIL 执よび LN-TIL について同様の検索を 行い, 養子免疫療法の移入細胞としての有用性について 検討した。

その結果, 以下のことが示された。

1. 口腔原発覀性腫瘍組織（28 検体）扣よび転移リン パ節組織（6 検体）全例から, TIL および LN-TIL の 分離が可能であった. 回収率, L/T 比ともに LN-TIL の値が有意に高值を示し，TIL と比較して効率よく回 収されることが示された。

また，TIL の回収率は横紋筋肉腫，悪性黒色腫のよ らな非上皮性腫瘍で高く, 術前治療の施行されない腫瘍 で高い傾向であった.ささに，LI grade の高い腫瘍で は TIL の回収率は高かった。

2. IL-2 単独での培養により, TIL は PBL と比較 して高い増殖能を示した. TIL の最大獲得細胞数は, $2.18 \times 10^{6} \sim 3.56 \times 10^{9}$ の範囲で, 平均 $3.17 \times 10^{7}$ 個であっ た。

また TIL の細胞増殖反応は IL-2 濃度依存性に増強 し, PBL より効率よく増殖することが示された.

さらに TIL から NK および LAK 活性の出現, 増 強が認められ, その活性は平均で培養 3 週目以降で PBL を上回るよらになり，その後も長期間維持された。

3. 口腔悪性腫瘍組織から分離された新鮮 TIL は, NK および LAK 活性をほとんど示さなかった。一方， 術前治療として腫瘍切除前に IL-2 の局所投与を行った 症例では, 新鮮 TIL の NK 活性の増強扣よび LAK 活性の出現が認められた。

4. 抗 CD3 抗体/IL-2 での培養により, TIL および LN-TIL は PBL と同様に高い増殖能を示し, それぞれ IL-2 単独で培盖した場合と比較して数十倍から数百倍 上回る值であった。 TIL 拈よび LN-TIL の最大獲得細 胞数は, TIL では $6.90 \times 10^{6}$ 個 $2.80 \times 10^{9}$ 個の範囲で

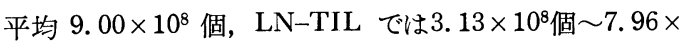
$10^{9}$ 個の範用で平均 $2.90 \times 10^{9}$ 個であった。 また，その NK および LAK 活性は PBL とほぼ同程度の值であっ たが，症例によりその NK および LAK 活性は 3 週目 以降で PBL を上回りその後も維持されることが示され た.

5. IL-2 活性化 TIL が培養自己腫瘍細胞（上顎洞, 横紋筋肉腫）および新鮮自己腫瘍細胞（上顎洞，横紋筋 肉腫) に対して障害活性を示す症例，および抗 CD3 抗 体/IL-2 活性化 LN-TIL が新鮮自己腫瘍細胞（口蓋, 悪性黒色腫）に対する障害活性を示す症例が認められ,
TIL および LN-TIL が自己腫瘍細胞に対して選択的な 細胞障害活性を有する可能性が示唆された。

以上の結果より, 口腔悪性腫瘍組織に浸潤している TIL から IL-2 による細胞障害活性 (NK, LAK 活性 および自己腫瘍細胞障害活性）の誘導が可能であった。 また IL-2 の腫瘍局所投与により, TIL の細胞障害活性 が生体内で増強する可能性が示唆された。 さらに抗 CD3 抗体执よび IL-2 での培養により，TIL および LNTIL の細胞増殖能 および 細胞障害活性が増強されるこ とから, 口腔悪性腫瘍患者に対する養子免疫療法の移入 細胞としての有用性が示された.

稿を終えるにあたり，ご懇切なるご指導，ご校閲を賜 りました榎本昭二教授に深甚なる感謝の意を表します。 また，本研究に際し終始ご愁切なるご指導とご助言を頂 きました高橋雄三博士に心から感謝の意を表します。さ らにご協力を頂きました口腔外科学第 2 講座教室員の皆 様に心からの謝意を表します。

本論文の要旨は, 第 46 回日本癌学会総会（昭和 62 年 9 月 7 日, 東京), 第 12 回日本頭頸部腫瘍学会 (昭和 63 年 7 月 7 日, 神奈川), 第 7 回日本歯科薬物療法学会（昭 和63年 7 月 23 日, 大阪), 第 1 回 JBRM 学会学術集会 総会 (昭和 63 年 11 月 12 日, 大阪), FIRST ASIAN CONGRESS-ORAL AND MAXILLOFACIAL SURGERY (16-19 March 1989, Manila, Philippines), 第 34 回日本口腔外科学会総会 (平成元年10月27日, 郡山), 第35回日本口腔外科学会総会 (平成 2 年 10 月 25 日, 岡 山）において発表した。

\section{引用文 献}

1) Handley, W.S.: The pathology of melanotic growth in relation to their operative treatment. The Lancet 6: 927-933 1907.

2) Black, M.M., Opler, S.R., et al.: Microscopic structure of gastric carcinomas and their regional lymph nodes in relation to survival. Surg Gynecol Obstet 98: 725-734 1954.

3）藤林孝司：口腔癌に扣ける細胞性免疫反応に関 する研究。口科誌 32: 657-695 1983.

4) Hiratuka, H., Imamura, M., et al.: Lymphocytes subpopulations and $\mathrm{T}$-cell subsets in human oral cancer tissues: Im!nunohistologic analysis by monoclonal antibodies. Am J Clin Pathol 81: 464-470 1984.

5) Hiratuka, H., Imamura, M., et al.: Immunohistologic detection of lymphocytes subpopulations infiltrating in human oral cancer with special 1 eference to its clinical significance. Cancer 53: 2456-2466 1984.

6) Morgan, D.A., Ruscetti, P.W., et al.: Selective 
in vitro growth of $\mathrm{T}$ lymphocytes from normal human bone marrows. Science 193: 100710081976.

7) 羽室淳爾 : インターロイキン. 講談社サイエン ティフィック，東京, 1984, 110-120頁.

8) Grimm, E.A., Mazumder, A., et al.: Lymphokine-activated killer cell phenomenon. Lysis of natural killerresistant fresh solid tumor cells by interleukin 2-activated autologous human peripheral blood lymphocytes. J Exp Med 155: 1823-1841 1982.

9) Rosenberg, S.A.: Adoptive immunotherapy of cancer. Accomplishments and prospects. Cancer Treat Rep 68: 233-255 1984.

10）石川隆, 井超道夫, 他: IL-2 による癌の免 疫療法一LAK 細胞注入療法一. Medical Immunol 12: 767-773 1986.

11) 仁井昌彦, 曽根三郎, 他 : Lymphokine activated killer (LAK) 細胞による湌子免疫療法. 癌 と化学療法 14: 1871-1876 1987.

12) Rosenberg, S.A., Spiess, P., et al.: A new approach to the adoptive immunotherapy of cancer with tumor-infiltrating lymphocytes. Science 233: 1318-1321 1986.

13) Rosenberg, S.A., Packard, B.S., et al.: Use of tumor-infiltrating lymphocytes and interleukin 2 in the immunotherapy of patients with metastatic melanoma. A preliminary report. New Engl J Med 319: 1676-1680 1988.

14) Ochoa, A.C., Gromo, G., et al.: Long-term growth of lymphokine-activated killer (LAK) cells: role of anti-CD3, $\beta$-IL1, interferon- $\gamma$ and $-\beta$. J Immunol 138: 2728-2733 1987.

15) Ochoa, A.C., Hasz, D.E., et al.: Lymphokine-activated killer activity in long-term cultures with anti-CD3 plus interleukin 2: identification and isolation of effector subsets. Cancer Res 49: 963-968 1989.

16）関根輝涁, 垣添忠生, 他: Tumor-Infiltrating Lymphocytes の培㽰とAdoptive Immunotherapy への応用. 癌と化学療法 16: 146914731989.

17）関根輝森：固相化 CD3 抗体により活性化した $\mathrm{T}$ cell (CD3-AT) を用いた㕌子免疫療法. BIOTHERAPY 4: 1606-1613 1990.

18) Schoof, D.D., Selleck, C.M., et al.: Activation of human tumor-infiltrating lymphocytes by monoclonal antibodies directed to the CD3 complex. Cancer Res 50: 1138-1143 1990.

19) Van Wauwe, J.P., De Mey, J.R., et al.: OKT3: a monoclonal anti-human $\mathrm{T}$ lymphocyte antibody with potent mitogenic properties. J Immunol 124: 2708-2713 1980.

20) Black, M.M., Speer, F.D., et al.: Structural representations of tumor-host relationships in mammary carcinoma. Biologic and prognostic significance. Am J Clin Pathol 26: 250-265 1956.

21）矢田純一, 藤原道夫：リンパ球機能検索法. 中 外医学社, 東京, 1983, 15-24頁.

22) Cerottini, J.C., Engers, H.D., et al.: Generation of cytotoxic $\mathrm{T}$ lymphocytes in vitro. I Response of normal and immune mouse spleen cells in mixed leukocyte cultures. J Exp Med 140: 703-717 1974.

23) Rosenberg, S.A., Lotze, M.T., et al.: A progress report on the treatment of 157 patients with advanced cancer using lymphokineactivated killer cells and interleukin-2 or highdose interleukin-2 alone. New Eng J Med 316: 889-897 1987.

24）高橋雄三，森 良之，他：口腔癌患者に打ける 抗 CD3 抗体拉よび IL-2 活性化自己リンパ球 (L.AK 細胞) の腫瘍集積性ならびに体内動態の 観察. 日口外誌 37：1249-1263 1991.

25）高橋雄三, 湊 秀次, 他: LAK 細胞障害活性 （NK おょび LAK 活性）ならびに細胞増殖に 対する放射線照射の影響. 頭頸部腫瘍 17：1871921991.

26）杉山芳樹：口腔癌組織浸潤リンパ球の免疫学的 研究. 日口外誌 29: 30-46 1983.

27) Itoh, K., Tilden, A.B., et al.: Interleukin-2 activation of cytotoxic T-lymphocytes infiltrating into human metastatic mela-nomas. Cancer Res 46: 3011-3017 1986.

28) Itoh, K., Platsoucas, C.D., et al.: Autologous tumor-specific cytotoxic $\mathrm{T}$ lymphocytes in the infiltrate of human metastatic melanomas. Activation by interleukin 2 and autologous tumor cells, and involvement of the $\mathrm{T}$ cell receptor. J Exp Med 168: 1419-1441 1988.

29）川上一岳, 大内明夫, 他 : インターロイキン 2 (IL-2) により活性化された腎細胞癌浸潤リン 弪球 (TIL) の免疫学的性状. BIOTHERAPY 4: 1780-1786 1990.

30) Belldegrun, A., Muul, L.M., et al.: Interleukin 2 expanded tumor-infiltrating lymphocytes in human renal cell cancer: isolation, characterization, and anti tumor activity. Cancer Res 48: 206-214 1988.

31）宮田佳代子, 湯山誠一朗, 他 : 頭頸部癌患者の tumor infiltrating lymphocytes(TIL)の增殖能 々抗腫瘍活性. 頭頸部腫瘍 15: 73-78 1989.

32) Hoe, D.S., Whiteside, T.L., et al.: Long-term interleukin 2-dependent growth and cytotoxic activity of tumor-infiltrating lymphocytes from human squamous cell carcinomas of the head and neck. Cancer Res 47: 6353-6362 1987.

33）森良之, 高橋雄三, 他 : 腫瘍組織浸潤リンパ 球 (TIL) からの rIL 2 による細胞障害活性の 
誘導. BIOTHERAPY 3: 80-84 1989.

34) Whiteside, T.L., Miescher, S., et al.: Separation, phenotyping and limiting dilution analysis of T-lymphocytes infiltrating human solid tumors. Int J Cancer 37: 803-811 1986.

35) Miescher, S., Whiteside, T.L., et al.: Functional properties of tumor-infiltrating and blood lymphocytes in patients with solid tumors: effect of tumor cells and supernatants on proliferative responses of lymphocytes. J Immunol 136: 1899-1907 1986.

36) Whiteside, T.L., Heo, D.S., et al.: Expansion of tumor-infiltrating lymphocytes from human solid tumors in interleukin-2.Cellular Immunotherapy of Cancer. Alan Liss, Inc., New York, 1987, p 213-222.

37）東みゆき：口腔癌患者における IL-2 活性化キ ラー細胞の誘導に関する研究. 日口外誌 34 : 438-450 1988.

38）田上正：口腔癌患者に拈ける natural killer (NK) 活性に関する研究. 日口外誌 29：2082231983

39) Eremin, O., Coombs, R.R.A., et al.: Lymphocytes infiltrating human breast cancers lack K-cell activity and show low levels of NKcell activity. Br J Cancer 44: 166-176 1981.

40）伊東恭悟, Balch, C.M., 他 : 腫瘍内浸潤リン 弪球 (TIL, Tumor Infiltrating Lymphocytes) とリンホカイン活性化リン パ球 (LAK Cells, Lymphokine Activated Killer Cells)ーヒト新 鮮分離癌細胞に対するキラー細胞とインターロ イキン 2 による活性化一. Oncologia 20：207120851987.

41) Rabinowich, H., Cohen, R., et al.: Functional analysis of mononuclear cells infiltrating into tumors: lysis of autologous human tumor cells by cultured infiltrating lymphocytes. Cancer Res 47: 173-177 1987.

42) Inoue, Y., Shijubo, N., et al.: Induction of killer cells from lymphocytes in pleural effusion of advanced lung cancer patients. Jpn J Cancer Res 81: 1012-1020 1990.

43) Vose, B.M.: Quantitation of proliferative and cytotoxic precursor cells directed against human tumors: limiting dilution analysis in peripheral blood and tumor site. Int $\mathrm{J}$ Cancer 30: 135-142 1982.

44) Keong, A. and Rabson, A.R.: Supernatants derived from a human hepatocellular carcinoma cell Line (PLC/PRF/5) activates a population of $\mathrm{T}$-suppressor cells. Cancer Immunol Immunother 15: 178-183 1983.

45）伊東恭悟：転移性メラノーマ腫瘍内に浸潤する リンパ球. 癌と化学療法 14：2119-2126 1987.

46）高橋雄三, 森 良之, 他: 口腔扁平上皮癌に対
する rIL2 の局所投与による臨床的ならびに免 疫学的治療効果. BIOTHERAPY 1: 99-106 1987.

47) Pizza, G., Severini, G., et al.: Tumour regression after intralesional injection of interleukin 2 (IL,-2) in bladder cancer. Preliminary report. Int J Cancer 34: 359-367 1984.

48) Muul, L.M., Spiess, P.J., et al.: Identification of spesific cytolytic immune responses against autologous tumor in humans bearing malignant melanoma. J Immunol 138: 9899951987.

49）青木陽一, 田中憲一: 腫瘍内浸潤リンパ球 (TIL)を用いた湌子免疫療法の現状と今後の展 望. BIOTHERAPY 4: 1600-1605 1990.

50) Pisani, R.J., I.eibson, P.J., et al.: In vitro activation of lymphocytes from nonsmall cell cancer patients by interleukin 2 and anti-CD3 antibody. Clin Immunol Immunopathol 50: 348-363 1989.

51）高橋雄三, 森 良之, 他：インターロイキン 2 活性化口腔癌患者末梢血リンパ球の自己新鮮腫 瘍細胞に対する細胞障害活性. 日口外誌 35 : 341-360 1989.

52) Lanier, L.L. and Phillips, J.H.: Evidence for three types of human cytotoxic lymphocytes. Immunol Today 7: 132-134 1986.

53) Hersey, P. and Bolhuis, R.: Nonspecific MHC-unrestricted killer cells and their receptors. Immunol Today 8: 233-239 1987.

54）熊谷勝男, 藤井昌彦, 他 : 腫瘍の増殖抑制に関 与寸るキラーリンパ球一ヒトでの解析. BIOTHERAPY 3: 620-628 1989.

55）森良之, 高橋雄三, 他: 口腔扁平上皮癌患者 リンパ球より誘尊された抗 CD3 抗体/IL-2 活 性化細胞 (CD3・LAK) の標的細胞認識の検索. 頭頸部腫瘍 18: 投稿中.

56) Okada, Y., Yahata, G., et al.: A correlation between the expression of CD8 antigen and specific cytotoxicity of tumor-infiltrating lymphocytes. Jpn J Cancer Res 80: 249-256 1989.

57）田中憲一：CTL の誘尊における腫瘍細胞の HLA 抗原発現の意義. BIOTHERAPY 3: 638-646 1989.

58) Chakraborty, N.G., Sporn, J.R., et al.: Suppresion of lymphokine-activated killer cell generation by tumor-infiltrating lymphocytes. Clin Immunol Immunopathol 59: 407-416 1991.

59）菅 典道, 三瀬圭一, 他：TIL 癌治療. 癌治 療と宿主 2: 29-36 1990.

60）堀泰祐, 菅 典道, 他：ヒト固型癌および癌 性胸腹水中の腫瘍浸潤リンパ球の抗腫瘍能とそ れを用いた癌治療の試み。日癌治 20：943-953 
1985.

61) 野村直弘, 上出利光, 他: 接着分子. 第 1 肘, メジルビュー社, 東京, 1991，92-103頁.

62) Wong, R.A., Alexander, R.B., et al.: In nvo proliferation of adoptively transferred tumorinfiltrating lymphocytes in mice. J Immunother 10: $120-1301991$. 